\title{
Molecular Mechanisms in Exercise-Induced Cardioprotection
}

\author{
Saeid Golbidi and Ismail Laher \\ Department of Pharmacology and Therapeutics, Faculty of Medicine, University of British Columbia, \\ Vancouver, BC, Canada V6T $1 Z 3$ \\ Correspondence should be addressed to Ismail Laher, ilaher@interchange.ubc.ca
}

Received 26 September 2010; Revised 16 December 2010; Accepted 3 January 2011

Academic Editor: Christina Chrysohoou

Copyright () 2011 S. Golbidi and I. Laher. This is an open access article distributed under the Creative Commons Attribution License, which permits unrestricted use, distribution, and reproduction in any medium, provided the original work is properly cited.

\begin{abstract}
Physical inactivity is increasingly recognized as modifiable behavioral risk factor for cardiovascular diseases. A partial list of proposed mechanisms for exercise-induced cardioprotection include induction of heat shock proteins, increase in cardiac antioxidant capacity, expression of endoplasmic reticulum stress proteins, anatomical and physiological changes in the coronary arteries, changes in nitric oxide production, adaptational changes in cardiac mitochondria, increased autophagy, and improved function of sarcolemmal and/or mitochondrial ATP-sensitive potassium channels. It is currently unclear which of these protective mechanisms are essential for exercise-induced cardioprotection. However, most investigations focus on sarcolemmal KATP channels, NO production, and mitochondrial changes although it is very likely that other mechanisms may also exist. This paper discusses current information about these aforementioned topics and does not consider potentially important adaptations within blood or the autonomic nervous system. A better understanding of the molecular basis of exercise-induced cardioprotection will help to develop better therapeutic strategies.
\end{abstract}

\section{Introduction}

It is generally accepted that regular exercise is an effective way for reducing cardiovascular morbidity and mortality [1]. Physical inactivity and obesity are also increasingly recognized as modifiable behavioral risk factors for a wide range of chronic diseases, including cardiovascular diseases. Furthermore, epidemiologic investigations indicate that the survival rate of heart attack victims is greater in physically active persons compared to sedentary counterparts [2]. Several large cohort studies have attempted to quantify the protective effect of physical activity on cardiovascular and all cause mortality. Nocon et al. [3] in a meta-analysis of 33 studies with 883,372 participants reported significant risk reductions for physically active participants. All-cause mortality was reduced by $33 \%$, and cardiovascular mortality was associated with a $35 \%$ risk reduction. Exercise capacity or cardiorespiratory fitness is inversely related to cardiovascular and all-cause mortality, even after adjustments for other confounding factors [4-6].

The American College of Sports Medicine defines exercise as "Any and all activity involving generation of force by the activated muscle(s) that results in disruption of a homeostatic state". Exercise is classified by the type, intensity, and duration of activity. Endurance exercise reflects prolonged and continuous periods of contractile activity (high repetition) against low resistance whereas resistance exercise (strength training) involves short periods of contractile activity (low repetition) against a high opposing resistance, while sprint exercise occurs during short periods of maximal (intense) repetitive contractile activity, where there is a short period of exercise against a low resistance, such as running a $100-\mathrm{m}$ sprint race. However, sprint training can also be performed against high resistance, which results in a combination of resistance and endurance modalities, for example, running with added weights [7].

Although it is clear that exercise promotes a cardioprotective phenotype, a detailed understanding of the cellular mechanisms responsible for this cardioprotection remains incomplete. The cytoprotective mechanisms that have garnered most attention are inducible heat shock proteins and antioxidant enzymes, especially superoxide dismutase (SOD) [8-11]. However, there are numerous clues suggesting that other mechanisms may also be part of exercise-induced 
cardioprotective phenotype, and they may have significant roles in the protective process. Improving our understanding of the molecular basis for exercise-induced cardioprotection will play an important role in developing optimal exercise interventions for primary and secondary prophylaxis. The objective of this paper is to summarize the body of knowledge related to the molecular basis of cardioprotective effects of exercise and the evidence for other potential mediators. We mainly focused on adaptations within the cardiac muscles and will briefly examine coronary adaptations as well. However, it should be noted that other adaptive mechanisms in the blood, humoral and autonomic nervous system, muscles, and so forth can also affect this process.

\section{Exercise-Induced Expression of HSPs in the Heart}

The ability of organisms to respond to various stressors was first described by Selye in 1936, who suggested a series of programmed events that help organisms to cope with the situation [12]. The heat shock response is a common cellular reaction to external stimuli such as ischemia [13], hypoxia [14], acidosis [15], oxidative stress [16], protein degradation [17], increased intracellular calcium [18], and energy depletion [19] (Table 1). Therefore, the terms "stress proteins" and "cellular stress response" reflect the array of stressors known to initiate heat shock protein (HSP) expression [20]. It is generally accepted that exercise increases the expression of cardiac HSPs. Locke et al. [21] performed a comprehensive study of the effects of acute exercise on myocardial expression of HSPs and showed that the expression of HSPs can begin within 30-60 min after an exercise bout in the rat myocardium. The mechanistic link between exercise and myocardial expression of HSPs is unclear. However, a variety of stresses associated with exercise, including heat stress and hypoxia, reduced intracellular $\mathrm{pH}$, reactive oxygen and nitrogen species (ROS and RNS) production, and depletion of glucose and glycogen stores, increase in cytosolic calcium levels and cardiomyocyte stretching can all contribute to HSP elevation in cardiac muscle [22]. Several stress proteins such as HSP10, HSP40, HSP60, and HSP90 are thought to play cardioprotective roles [23, 24], with some detailed understanding of the role of the HSP70 family [25]. Production of HSP70 in the rat myocardium during treadmill running is mediated by an increase in the activation of heat shock transcription factor 1 (HSF 1), which then binds to the heat shock element of HSP70 genes and results in increased levels of HSP70 mRNA [26]. In an attempt to provide additional insights, Melling et al. showed that protein kinase A (PKA), and not protein kinase C, plays a key role in exercise-induced regulation of HSP70 gene expression [27]. Activation of PKA mediates the suppression of an intermediary protein kinase, extracellular signal regulated kinases (ERK1/2), which phosphorylates and suppresses the activation of the HSF1. However, following exercise training, ERK1/2 regulates the transcriptional activation of several genes involved in cell growth and proliferation and has been shown to be associated with training-mediated myocardial hypertrophy. In another study, Melling et al.
[28] reported increased expression of HSP70 following a single bout of exercise in the presence of elevated ERK $1 / 2$ in trained animals. These results suggest that training results in adaptations that allow for the simultaneous initiation of both proliferative and protective responses. In addition, HSP72 (a member of HSP70 family) augments myocardial antioxidant capacity [29]. During ischemia/reperfusion (I/R) insult, HSP72 preserves mitochondrial function and provides cellular protection against apoptosis [30, 31]. Moreover, by prevention of protein aggregation and denaturation, HSP72 also enhances recovery from acute cellular injury and so protects cells from subsequent injury [32].

Although exercise induces cardiac HSP72 expression (which is cardioprotective), there are some reports demonstrating that the beneficial effects of exercise on cardiac muscle is independent of HSPs formation [33]. Hamilton et al. postulated that exercise associated cardioprotection may depend, in part, on increases in myocardial content manganese superoxide dismutase (MnSOD), rather than HSP levels [34], while studies by Quindry et al. suggest that exercise-induced myocardial protection against $\mathrm{I} / \mathrm{R}$ is unrelated to increases in cardiac levels of HSP10, HSP27, HSP40, HSP60, HSP72, HSP73, or HSP90 [35, 36]. One explanation for these findings is the activation of cardioprotective mechanisms through different pathways that then converge on common distal pathways, suggesting that exercise-induced cardioprotection could be achievable through multiple mechanisms.

\section{Exercise and Myocardial Antioxidant Capacity}

Cells have evolved highly complex antioxidant systems (enzymic and nonenzymic), which work synergistically to protect cells and organ systems of the body against free radical-induced damage. The most efficient enzymatic antioxidants involve glutathione peroxidase, catalase, and superoxide dismutase. Nonenzymatic antioxidants include vitamins $\mathrm{E}$ and $\mathrm{C}$ and thiol antioxidants (glutathione, thioredoxin) [38]. Each of these antioxidants is capable of combining with reactive oxidants to produce other less reactive spices. Superoxide dismutase promotes the dismutation of the superoxide radical to form hydrogen peroxide $\left(\mathrm{H}_{2} \mathrm{O}_{2}\right)$ and oxygen. While glutathione peroxidase $(\mathrm{GPx})$ uses reduced glutathione (GSH), as a reducing equivalent, to reduce $\mathrm{H}_{2} \mathrm{O}_{2}$ to form oxidized glutathione and water. Furthermore, GSH can remove selected oxygen radicals directly and assist in the recycling of vitamin $\mathrm{C}$ and $\mathrm{E}$ (Table 2).

Catalase converts $\mathrm{H}_{2} \mathrm{O}_{2}$ to water and oxygen. The newly identified peroxiredoxin family represents a group of peroxidases that also catalyze the reduction of $\mathrm{H}_{2} \mathrm{O}_{2}$. They include at least six isoforms in mammalian cells [39]. Among them, peroxiredoxin III is synthesized with a mitochondrial targeting sequence, as is MnSOD.

The effects of exercise on myocardial antioxidant enzyme activities has been widely investigated but with variable conclusions. For example, while some studies report that exercise-induced increases in GPx activity [40, 41], others 
TABLe 1: Cellular location and function of selected heat shock proteins (HSPs) [22, 23, 32, 37].

\begin{tabular}{|c|c|c|c|}
\hline Family & Members & Cellular location & Proposed function (comment) \\
\hline Ubiquitin & Ubiquitin & Cytosol & $\begin{array}{l}\text { Protein degradation (ubiquitin levels in cells increase following } \\
\text { cellular injury) }\end{array}$ \\
\hline HSP10 & HSP10 & Mitochondria & Molecular chaperons, cofactor for HSP60 \\
\hline HSP27 & $\begin{array}{l}\text { HSP27, HSP26, and so } \\
\text { forth }\end{array}$ & Cytosol, nucleus & $\begin{array}{l}\text { Microfilament stabilization, antiapoptotic (variable in size and } \\
\text { number in different organisms) }\end{array}$ \\
\hline HSP60 & HSP60 & Mitochondria & $\begin{array}{l}\text { Refolds proteins and prevents aggregation of denatured proteins, } \\
\text { proapoptotic. }\end{array}$ \\
\hline HSP70 & $\begin{array}{l}\text { HSP72, HSP73, HSP75, } \\
\text { HSP78 }\end{array}$ & $\begin{array}{l}\text { Cytosol, nucleus, } \\
\text { mitochondria, endoplasmic } \\
\text { reticulum }\end{array}$ & $\begin{array}{l}\text { Molecular chaperons, protein folding, and cytoprotection (HSP72 } \\
\text { postulated to play an important role in myocardial protection } \\
\text { against I/R injury). }\end{array}$ \\
\hline HSP90 & HSP90, HSP100, Grp94 & Cytosol, nucleus, ER & $\begin{array}{l}\text { May function as a molecular chaperone during maturation of } \\
\text { steroid receptors and assists in the folding of newly synthesized } \\
\text { peptides, protein translocation. }\end{array}$ \\
\hline
\end{tabular}

suggest that myocardial GPx activity is not altered by exercise $[42,43]$. Such equivocal results have also been reported for myocardial catalase, with increased $[44,45]$ and decreased $[33,43]$ levels. Although there is no clear explanation for these discrepancies, it is possible that the use of exercise protocols that differ in duration and intensity may be an important underlying factor. The strongest evidence to directly link increases in myocardial antioxidants and exercise-induced cardioprotection implicates a contributory role for MnSOD. It is generally believed that even short-term endurance exercise results in a rapid increase in myocardial MnSOD activity $[43,46,47]$ as shown in studies that employed antisense oligonucleotide techniques to silence MnSOD genes and so prevent exercise-induced increases in myocardial MnSOD activity [46, 48]. For example, Yamashita et al. [46] reported that inhibition of exerciseinduced increases in cardiac MnSOD abolished protection against myocardial infarction, findings that were confirmed by Hamilton et al. [49] who concluded that MnSOD plays a key role against I/R-induced cardiac arrhythmias. In contrast, Lennon et al. [50] reported that exercise-induced increases in cardiac MnSOD activity is not essential to achieve exercise-mediated protection against myocardial stunning. It is possible that mechanisms responsible for exercise-induced protection against myocardial stunning are different from those involved in myocardial arrhythmias and infarction [51] (Figure 1).

\section{Additional Mechanisms Involved in Exercise-Induced Cardioprotection}

The induction of myocardial HSPs and upregulation of cardiac antioxidant enzymes are well-studied aspects of the response to exercise. Other related responses to exerciseinduced cardioprotection include anatomical and physiological changes in the coronary arteries, increased myocardial cyclooxygenase-2 (COX-2) activity, elevated endoplasmic reticulum stress proteins, nitric oxide production, increased autophagy, and improved function of sarcolemmal and/or mitochondrial ATP sensitive potassium (sarco $\mathrm{K}_{\mathrm{ATP}}$ and/or mito $\mathrm{K}_{\mathrm{ATP}}$ ) channels [52] (Figure 2).

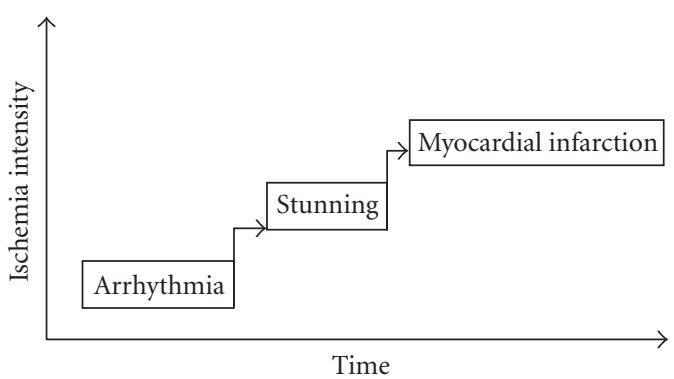

FIGURE 1: Sequence of pathologic events in ischemia reperfusion injury.

\section{Myocardial Collateral Circulation}

Exercise-induced adaptation of the coronary circulation can be divided into two major processes: (a) angiogenesis, which is an expansion of the capillary network by the formation of new blood vessels and occurs at the level of capillaries and resistance arterioles, but not in large arteries and (b) arteriogenesis, which is as enlargement of existing vessels [53].

5.1. Angiogenesis. It has been speculated that endurance exercise stimulates angiogenesis by either a division of preexisting endothelial cells or by bone marrow-derived endothelial progenitor cells and monocyte or macrophage derived angiogenic cells [54]. Some reports indicate that physical activity improves the mobilization of endothelial progenitor cells in healthy subjects and in patients with cardiovascular risk and coronary artery disease $[55,56]$. Indeed, angiogenesis is regulated by a net balance between positive (angiogenic) and negative (angiostatic) regulators of blood vessel growth. A balance favoring predominantly positive regulators are an angiogenic phenotype whereas a shift favoring negative regulators is an angiostatic phenotype. Therefore, an impaired regulation of angiogenesis is often associated with the development of angiogenesis-dependent diseases such as atherosclerosis. 


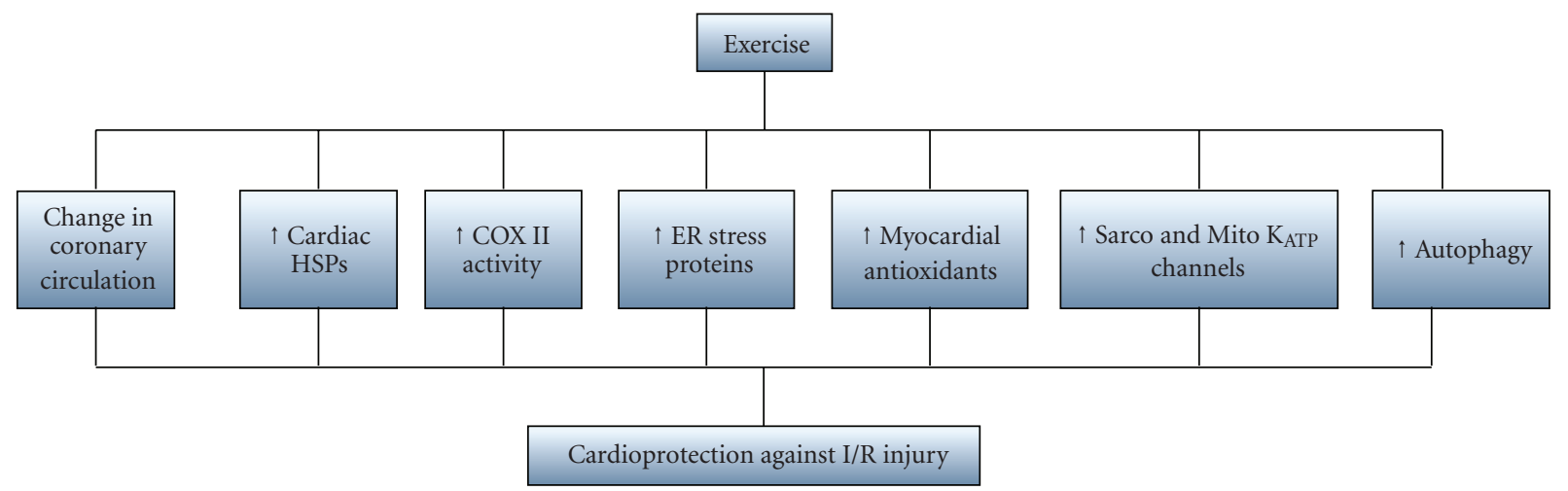

Figure 2: Proposed mechanisms for exercised-induced cardioprotection.

Endostatin is an endogenous angiostatic factor identified originally in conditioned media of murine hemangioendothelioma cells $[57,58]$. Many studies have shown that the proteolytic release of endostatin from collagen XVIII is mediated by proteases of many classes, such as cysteine proteases, matrix metalloproteases, and aspartic proteases $[59,60]$. The potent antiangiogenic effects of endostatin are mediated via a combination of effects on endothelial cells, where endostatin inhibits cellular proliferation and migration and stimulates apoptosis $[61,62]$. The biological effects of endostatin are mainly attributed to its antagonism of vascular endothelial growth factor (VEGF) signaling [63].

Angiogenesis has both beneficial and deleterious effects in atherosclerosis. While increased angiogenesis in cardiac tissue may be a favorable sign in the healing of the ischemic tissues [64], progressive angiogenesis in a primary atherosclerotic lesion could be a cause of plaque expansion $[65,66]$. There are several studies showing that exercise induces a local angiogenic phenotype characterized by overexpression of VEGF in skeletal muscle [67] and heart [64]. This phenomenon can prevent ischemia in these tissues. Exercise can also exert beneficial effects against atherosclerosis by increasing circulating endostatin, which inhibits development of atherosclerotic plaque through blocking angiogenesis in the plaque tissue [68]. Meanwhile, Brixius et al. also reported that endurance activity improves angiogenesis by reducing endostatin plasma levels [69]. Even though the different exercise protocols in these experiments can explain these discrepant results, further studies are needed to elucidate the precise mechanisms.

5.2. Arteriogenesis. Exercise training increases the diameter of large arterioles, small arteries, and conduit arteries. Another important aspect of exercise-induced changes in capillarity is the onset and persistence of exercise-induced arteriogenesis. The induction of arteriogenesis is an important vascular adaptation [70], since arteriogenesis leads to the formation of large conductance arteries capable of compensating for the loss of function of occluded arteries. Animal studies and clinical observations provide evidence for a significant correlation between regular physical exercise and increased coronary artery lumen diameter $[71,72]$. In one study, an 8-week training programme increased the contractile response to low doses of dobutamine in patients with chronic coronary artery disease and having a left ventricular ejection fraction below $40 \%$. This implies that short-term exercise training can improve quality of life by improving left ventricular systolic function during mild to moderate physical activity in patients with ischemic cardiomyopathy [73]. Moreover, eight patients with coronary heart disease and exertional angina pectoris successfully completed an 1115 week programme of endurance exercise conditioning. Angina threshold was determined by upright bicycle ergometer exercise and by atrial pacing. The product of heart rate and arterial systolic blood pressure at the exercise angina threshold was higher after conditioning, suggesting that conditioning increased the maximum myocardial oxygen supply during exercise [74].

\section{Cyclooxygenase II and Exercise-Induced Cardioprotection}

The phenomenon of ischemic preconditioning whereby brief episodes of sublethal ischemia renders the myocardium resistant to subsequent ischemic stress occurs in two phases: (i) an early phase that starts within a few minutes after the initial ischemic stimulus, lasts for $2-3 \mathrm{~h}$, and is due to adenosine and bradykinin release and (ii) a second phase, which begins $12-24 \mathrm{~h}$ later and lasts for 3-4 days $[75,76]$. This later phase of ischemic preconditioning is caused by the simultaneous activation of multiple stress responsive signaling pathways, including COX-2 and the inducible form of nitric oxide synthase (iNOS), resulting in the heart developing a phenotype that confers sustained protection against both reversible (stunning) and irreversible (infarction) myocardial I/R injury [76]. Similar to ischemic stimuli, both short- (1-3 days) and long-term (weeksmonths) exercise protocols are equally effective in conferring cardioprotection against I/R injury $[77,78]$.

Given the phenotypic similarities between ischemic and exercise preconditioning, and since COX-2 and iNOS are required to achieve the late phase of ischemic preconditioning-induced cardioprotection against both I/R stunning 
TABLE 2: Major antioxidants.

\begin{tabular}{|c|c|c|c|}
\hline & Name & Role & Remarks \\
\hline \multirow[t]{3}{*}{$\begin{array}{l}\text { Endogenous } \\
\text { enzymes }\end{array}$} & $\begin{array}{l}\text { Superoxide dismutase (SOD) } \\
\text { (a) mitochondrial } \\
\text { (b) cytoplasmic } \\
\text { (c) extracellular }\end{array}$ & Dismutase superoxide to $\mathrm{H}_{2} \mathrm{O}_{2}$ & $\begin{array}{l}\text { (a) Contains manganese (MnSOD) } \\
\text { (b) Contains copper and zinc (CuZnSOD) } \\
\text { (c) Contains copper (CuSOD) }\end{array}$ \\
\hline & Catalase & Dismutase $\mathrm{H}_{2} \mathrm{O}_{2}$ to $\mathrm{H}_{2} \mathrm{O}$ & Present in peroxisomes \\
\hline & Glutathione peroxidase & Removes $\mathrm{H}_{2} \mathrm{O}_{2}$ and lipid peroxides & $\begin{array}{l}\text { Selenoproteins (contains } \mathrm{Se}^{2+} \text { ) } \\
\text { Primarily in the cytosol also mitochondria }\end{array}$ \\
\hline \multirow{3}{*}{$\begin{array}{l}\text { Nonenzymatic } \\
\text { substance }\end{array}$} & Vitamin E & $\begin{array}{l}\text { Lipid peroxidation, scavenges } \\
\text { superoxide, hydroxyl and lipid } \\
\text { peroxide }\end{array}$ & Fat soluble \\
\hline & Vitamin C & $\begin{array}{l}\text { Scavenges superoxide, hydroxyl } \\
\text { radicals and } \mathrm{H}_{2} \mathrm{O}_{2} \text {, contributes to } \\
\text { regeneration of vit E. Neutralizes } \\
\text { oxidants from stimulated } \\
\text { neutrophils }\end{array}$ & Water soluble \\
\hline & $\beta$-carotene (provitamin $\mathrm{A}$ ) & $\begin{array}{l}\text { Scavenges } \cdot \mathrm{OH}, \mathrm{O}_{2} \cdot-\text { and peroxy } \\
\text { radicals } \\
\text { Prevents oxidation of vitamin A } \\
\text { Binds to transition metals }\end{array}$ & Water soluble \\
\hline
\end{tabular}

and infarction [76, 79], it had been postulated that COX2 activity, and subsequent prostanoids production, may also be essential for exercise-induced cardioprotection [80]. However, Nagy et al. reported that COX II inhibition did not prevent exercise-induced cardioprotection against ventricular arrhythmias after coronary occlusion in dogs [81]. Accordingly, studies by Quindry et al. $[82,83]$ revealed that exercise does not elevate cardiac COX-2 activity. Therefore, we conclude that different mechanisms may be responsible for cardioprotection afforded by ischemia preconditioning and aerobic exercise.

\section{Exercise-Induced Cardioprotection by Endoplasmic Reticulum Stress Proteins}

Another candidate mechanism explaining exercise-induced cardioprotection is through a family of cardioprotective protein collectively called endoplasmic reticulum (ER) stress proteins. During a cardiac I/R insult, the ER helps cellular homeostasis by maintaining intracellular calcium regulation and protein folding [84]. Malfunction of the ER during an $\mathrm{I} / \mathrm{R}$ event can lead to both mitochondrial-dependent and mitochondrial-independent cell death due to disruption of calcium homeostasis and/or impaired protein folding [85]. The two most important ER stress proteins are Grp78 and Grp94 which belong to HSP families and are overexpressed in cultured cardiomyocytes during oxidative stress and calcium overload [86]. Martindale et al. suggested that the unfolded protein response (UPR) is activated in the heart during I/R, where formation of "Activation of Transcription Factor 6 (ATF6)" induces the expression of proteins such as Grp78 and Grp94, which in turn reduces I/R-induced necrosis and apoptosis in the heart [87]. Since overexpression of these ER stress proteins provide ER protection during an $I / R$ insult, it may be that these proteins contribute to exerciseinduced cardioprotection. However, studies by Murlasits et al. demonstrate that at least short-term exercise training does not elevate ER stress proteins, and therefore, short-term exercise-induced cardioprotection may not be linked to ER stress adaptation [88].

\section{Nitric Oxide and Exercise-Induced Cardioprotection}

Nitric oxide plays a fundamental role in protecting the heart against I/R injury. Specifically, it plays a critical bifunctional role as a trigger and a mediator of late phase of preconditioning. Increased production of NO by eNOS is an important trigger in the late phase of ischemia and exerciseinduced preconditioning, and enhanced NO production by iNOS is mandatory in the mediation of the antistunning and antiinfarct actions of late preconditioning [89]. In other words, the heart responds to ischemia by using two types NOS isoforms in a harmonized manner; it uses preexisting eNOS for a prompt burst of NO production, while at the same time, there is upregulation of iNOS to switch to a defensive phenotype by a sustained enhancement of $\mathrm{NO}$ biosynthesis. The exact cardioprotective mechanisms of NO during I/R is a subject of much debate; however, hypothesized mechanisms include inhibition of calcium influx into myocytes [90], antagonism of $\beta$-adrenergic stimulation [91], reduction in cardiac oxygen consumption $[92,93]$, and actions on sarco $K_{\text {ATP }}$ channels [94].

Although there are many studies on the cardioprotective effect of nitric oxide in I/R-induced preconditioning, there are less investigations evaluating the protection afforded by nitric oxide in exercise-induced cardioprotection. Exercise increases the expression and activity of eNOS, likely due 
to changes shear stress, which modulates the production of NO [95-97]. Besides its vascular and metabolic effects (vasodilation, altered carbohydrate metabolism) [98], NO possess a number of physiological properties which makes it a cardioprotective molecule in the setting of myocardial I/R injury. For example, NO reversibly inhibits mitochondrial respiration [99] and apoptosis [100]. This effect results in a reduction in mitochondrial-induced cardiac injury in the failing human heart. Babai et al. showed that even a single period of exercise affords delayed protection against I/Rinduced ventricular tachycardia and other ischemic changes that are mediated by NO [101]. Further evidence for a central role of eNOS in exercise physiology comes from experiments with eNOS deficient mice $\left(\mathrm{eNOS}^{-/-}\right)$. Running capacity in these animals is $50 \%-60 \%$ less than age-matched wild-type mice $[102,103]$. de Waard et al. found that the beneficial effects of exercise after MI on LV remodeling and dysfunction depends critically on endogenous eNOS. They observed that the lack of one eNOS allele is sufficient to negate all beneficial effects of exercise, strongly suggesting that the beneficial effects of exercise depends on full eNOS expression [104]. Taylor et al. in an in vitro setting showed that exercise can render a cardioprotective phenotype against $\mathrm{I} / \mathrm{R}$ insult even in the presence of blockade of all NOS isoforms with L-NAME, leading them to conclude that acute exercise-induced preconditioning is not mediated by NOS (or either increases in HSP 72 or other antioxidant enzymes) [105]. These discrepant findings can be accounted for by considering the role of nitrite and nitrates in the physiology of the cardiovascular system. For example, it has been shown that nitrite (and nitrates) acts as a storage reservoir on $\mathrm{NO}$ so that under pathological conditions such as ischemia and hypoxia, nitrite can readily be reduced to NO $[106,107]$. The beneficial effect of nitrite therapy (which generates NO-independent of eNOS) has been shown in animal models of cardiac I/R injury [108, 109]. Nitrite levels are increased following exercise in both rodents and humans $[110,111]$. Since nitrite accumulated in the heart can provide cardioprotection during an ischemic event by being reduced to NO, it is likely that NO produced from endothelial cells during exercise can be oxidized to nitrite, transported in the plasma to then affect the heart or vasculature. In the case of myocardial ischemia, nitrite can be reduced back to $\mathrm{NO}$ and exert cardioprotection in an NO-dependent manner [112]. This hypothesis potentially could be applied to all the experiments in which exercise-induced cardioprotection was not abolished in the presence of an inhibitor of NOS $[105,113]$. To add to the importance of $\mathrm{NO}$ in exercise physiology is its ability to activate $\mathrm{K}_{\mathrm{ATP}}$ channels through cGMP-PKG signaling [114, 115] and to increase expression of HSP70 [116] during exercise.

\section{Role of Sarco and Mito $K_{\mathrm{ATP}}$ Channels in Exercise-Induced Cardioprotection}

Several lines of evidence indicate that sarco $\mathrm{K}_{\mathrm{ATP}}$ channels are involved in cardiac I/R injury. The $\mathrm{K}_{\mathrm{ATP}}$ channel was first described in 1983 and was named for the inhibitory effect of cytosolic ATP on potassium channel opening [117].
During ischemia, heart cells become energy depleted, which leads to increased anaerobic glycolysis to compensate for ATP depletion. The resulting acidosis increases the influx of $\mathrm{Na}$ via the $\mathrm{Na} / \mathrm{H}$ exchanger and inhibits the ATPdependent sarcolemmal $\mathrm{Na} / \mathrm{K}$ ATPase to augment the initial accumulation of $\mathrm{Na}$ [118]. The high intracellular $\mathrm{Na}$ concentration prompts the $\mathrm{Na} / \mathrm{Ca}$ exchanger to work in the reverse mode, producing cytosolic and mitochondrial Ca overload [119]. Upon reperfusion, a burst of ROS is generated by mitochondria, while intracellular $\mathrm{Na}$ overload continues as a result of the impaired function of $\mathrm{Na} / \mathrm{K}$ ATPase (Figure 3(a) and $3(\mathrm{~b}))$.

The $\mathrm{Na} / \mathrm{K}$ ATPase pump is a transmembrane heterodimer protein composed of $\alpha$ and $\beta$ subunits. The cytoplasmic domain of $\alpha$ subunit interacts with ankyrin, a protein that connects the $\mathrm{Na} / \mathrm{K}$ ATPase to the fodrin-based membrane skeleton [120]. Ankyrin and fodrin are major components of the membrane cytoskeleton in a variety of nonerythroid cells [121]. They are also substrates of calpains, a group of nonlysosomal Ca-dependent proteases. Previous studies demonstrated activation of calpain leading to the degradation of both ankyrin and fodrin during reperfusion [120]. The resulting increased intracellular concentrations of $\mathrm{Na}$ and $\mathrm{Ca}$, along with low ATP levels, lead to additional mitochondrial ROS production and to activation of other proteases, which result in decreased sarcoplasmic reticulum calcium transport and dysfunctional contractile proteins [122]. Increased cytosolic Ca levels also contribute to the opening of the mitochondrial permeability transition pore (mPTP), resulting in a loss of mitochondrial membrane potential and reduced ATP production [123]. The decrease in ATP production leads to opening of $\mathrm{K}_{\text {ATP }}$ channels on both the sarcolemmal and mitochondria. It was Noma [117] who initially hypothesized that opening of sarco $\mathrm{K}_{\mathrm{ATP}}$ channels induced by hypoxia, ischemia, or pharmacological $\mathrm{K}_{\text {ATP }}$ openers shortens the cardiac action potential duration by accelerating phase III repolarization. An enhanced phase 3 repolarization would inhibit Ca entry into the cell via Ltype channels and prevent Ca overload. Furthermore, the slowing of depolarization would also reduce $\mathrm{Ca}$ entry and slow or prevent the reversal of the $\mathrm{Na} / \mathrm{Ca}$ exchanger. These actions would increase cell viability via a reduction in $\mathrm{Ca}$ overload during ischemia and early reperfusion. Additional evidence supporting the protective role of sarco $\mathrm{K}_{\mathrm{ATP}}$ channels was provided by other investigators [123-127]. Exercise training increases the expression of cardiac sarco $K_{\mathrm{ATP}}$, and moreover, pharmacological blockage of these channels impairs cardioprotection [128]. The sex-specific and exercise acquired resistance to myocardial I/R injury is dependent on sarco $\mathrm{K}_{\mathrm{ATP}}$ activity during ischemia [129]. Interestingly, female animals have higher sarco ATP sensitive potassium channel expression [130] and estrogen can upregulate the expression of these channels [131]. Administration of HMR1098, a sarcolemmal $\mathrm{K}_{\mathrm{ATP}}$ channel blocker, abolished the sex-dependent differences in infarct size [132, 133]. It is likely that the smaller infarct size in female hearts reported in some studies may be related to an increase activity of protein kinases B (also known as Akt) and C [134], which cause increased recruitment of $K_{\text {ATP }}$ in myocyte 


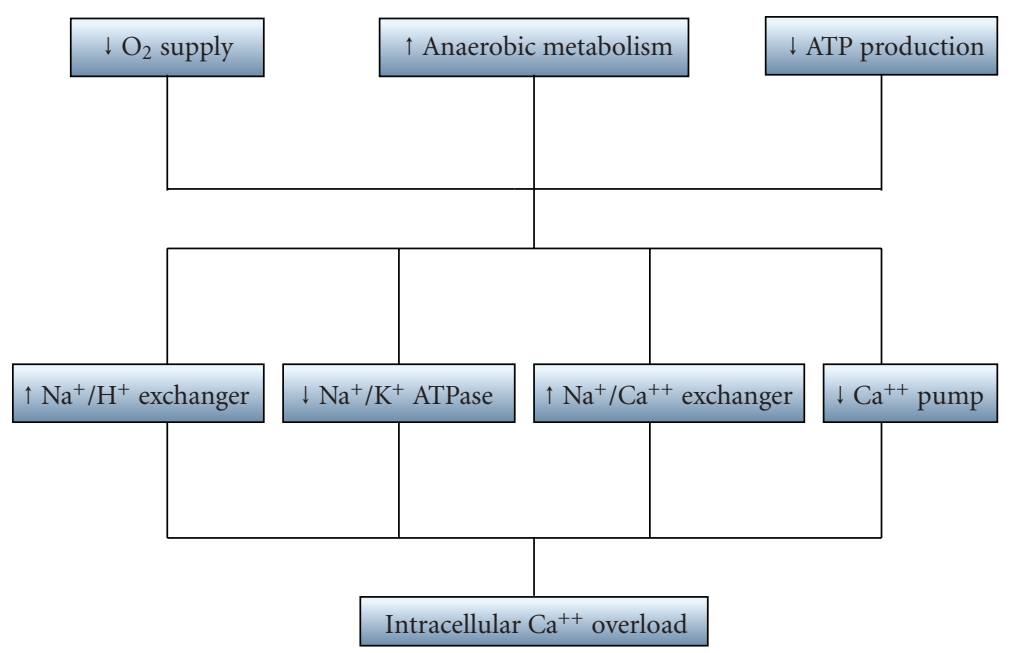

(a) Ischemia

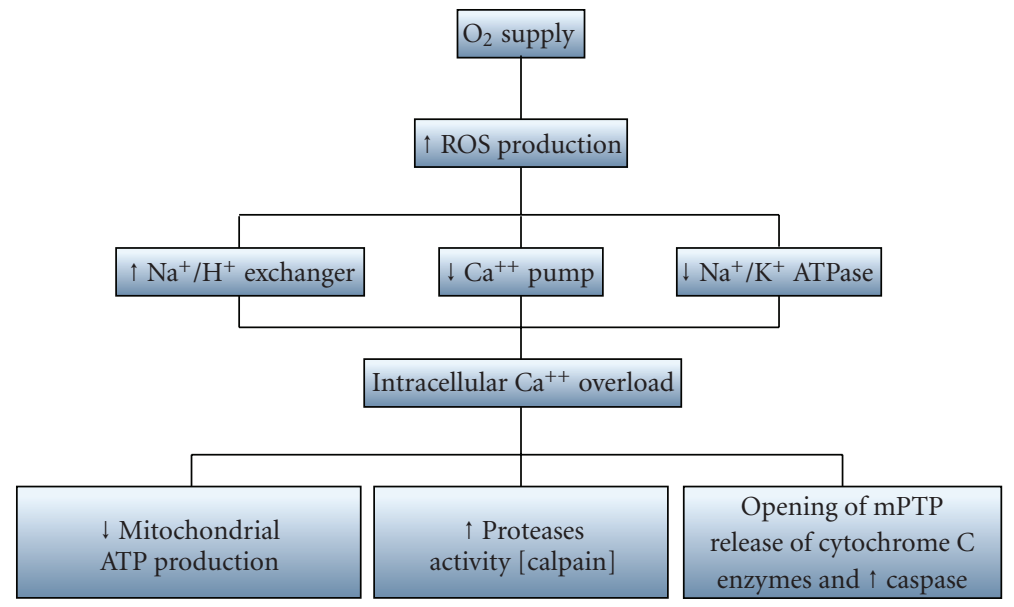

(b) Reperfusion

Figure 3: ( $a, b)$ Pathophysiological consequences of (a) ischemia and (b) reperfusion. (mPTP, mitochondrial permeability transition pore).

sarcolemma. Inhibition of these kinases before ischemia expanded infarct size in female (but not male) hearts. Recent studies suggest that inhibition of $\mathrm{K}_{\mathrm{ATP}}$ channels and of PKC are not additive, suggesting that activation of PKC and $K_{\text {ATP }}$ channels are different components of the same signaling pathway [135]. Activation of PKC by adenosine downregulates $\mathrm{K}_{\mathrm{ATP}}$ channels [136]. It is possible that on type of PKC is active following exercise which upregulates $\mathrm{K}_{\mathrm{ATP}}$ channels, while the activation of adenosine receptors activate another type of PKC which downregulates these channels [137]. The fact that PKC mediated activation of sarco $\mathrm{K}_{\mathrm{ATP}}$ channels is sex dependent suggests the presence of regulatory component(s) that either may not be present, or regulated in a different manner, in males. These findings show the complexity of signaling pathway(s) that regulate the density and function of sarco $\mathrm{K}_{\mathrm{ATP}}$ channels in preconditioned and nonpreconditioned hearts in a gender-dependent manner. A full understanding of the mechanisms underlying regulation of sarco $\mathrm{K}_{\mathrm{ATP}}$ is an exciting task for the future that certainly will have a significant impact on therapeutic strategies for the prevention and treatment of cardiovascular diseases.

Several lines of evidence confirm the role of mitochondrial $\mathrm{K}$ channels in protection against I/R injury [138140]. Prostacyclin analogs protect cardiac myocytes from oxidative stress mainly via activation of type 3 of $\mathrm{PE}_{2}$ receptors during $\mathrm{I} / \mathrm{R}$ injury. Activation of these receptors primes the opening of mitochondrial $\mathrm{K}_{\mathrm{ATP}}$ channels [141]. However, there is some controversy about the role of mito $\mathrm{k}_{\text {ATP }}$ channels in exercise preconditioning of the heart. For example, Domenech et al. reported that the early effect of exercise preconditioning of the heart is mediated through mito $k_{\text {ATP }}$ channels [142], while Brown et al. reported that mito $\mathrm{k}_{\text {ATP }}$ channels are not an essential mediator of exercise-induced protection against I/R-induced myocardial infarction [128]. It has also been recently suggested that mito $K_{\text {ATP }}$ channels provide antiarrhythmic effects as part of exercise-induced cardioprotection against I/R injury [143]. It should be mentioned that the molecular characteristics of 
mito $k_{\text {ATP }}$ channels remains elusive. Additional research is needed before definitive conclusions can be drawn.

\section{Exercise and Cardiac Mitochondria}

There is an important role for mitochondria in I/R injury. Exercise training results in cardiac mitochondrial adaptations that result in decreased ROS production, increasing their ability to tolerate high calcium levels. Lifelong voluntary wheel running reduced cardiac subsarcolemmal and interfibrillar mitochondrial hydrogen peroxide production in rats [144]. Similarly, endurance exercise reduces ROS production in myocardial mitochondria, resulting in less calcium influx upon reperfusion [145]. Reduction in ROS production could be related to decreased superoxide production or increased mitochondrial antioxidant enzyme activity. A study by Judge et al. [144] indicated that MnSOD activity was significantly lowered in subsarcolemmal and interfibrillar mitochondria, leading to the suggestion this may reflect a reduction in mitochondrial superoxide production. However, this issue is currently a matter of considerable debate.

Mitochondria of exercised animals are able to tolerate higher levels of calcium. Mitochondria isolated from hearts of exercised animals are more resistant to calcium-induced mPTP opening [146]. Furthermore, exercise training induces a mitochondrial phenotype that is protective against apoptotic stimuli [147]. These changes include increases in the protein levels of primary antioxidant enzymes in both subsarcolemmal and interfibrillar mitochondria, attenuation of ROS-induced cytochrome $c$ release, reduced maximal rates of $\mathrm{mPTP}$ opening $\left(\mathrm{V}_{\max }\right)$, and prolonged time to $\mathrm{V}_{(\max )}$ in both subsarcolemmal and interfibrillar mitochondria, and increased levels of antiapoptotic proteins including the apoptosis repressor with a caspase recruitment domain. These results are consistent with the concept that exerciseinduced mitochondrial adaptations contribute to exerciseinduced cardioprotection and are compatible with our study on the effect of exercise on renal mitochondria in diabetic mice [148].

Monoamine oxidase enzymes are located on the outer mitochondrial membrane and are divided into 2 major forms A and B based on genetic criteria, substrate specificity, and inhibition by synthetic compounds. The degradation of biogenic amines (serotonin and catecholamines) is the major physiological function of these enzymes [149] and MAO$\mathrm{A}$, which is the predominant isoforms expressed in cardiac ventricle, also represents an important source of ROS in the heart [150]. Moreover, its ability to produce ROS increases with aging and its expression is upregulated during cardiac hypertrophy and failure [151]. A study by Bianchi et al. investigating the potential role of ROS generated by MAOA during 5-HT degradation in cardiomyocyte death and its role in post-I/R damage showed that MAO is responsible for receptor-independent apoptotic effects of 5-HT in cardiomyocytes and post-ischemic myocardial injury. They also provided evidence that $\mathrm{H}_{2} \mathrm{O}_{2}$ production by MAO-A plays a critical role in post $\mathrm{I} / \mathrm{R}$ events leading to cardiac damage [152]. Another in vivo study using MAO-A knockout mice showed that these animals were protected from I/R-induced cardiac damage and this protection was related to significantly lower ROS generation following I/R injury [153]. Interestingly, Kavazis et al. showed that MAO-A protein levels were significantly reduced in both subsarcolemmal and intermyofibrillar mitochondria following exercise training [154]. They proposed that down regulation of MAO-A protein expression following endurance exercise is one of the mechanisms for exercise-induced cardioprotection.

Other effects of exercise on cardiac mitochondria relates to proteins involved in bioenergetics. This regulation may help to meet the increased energy demands during exercise or improved cardiac function during resting conditions. Thus, repeated bouts of exercise increase the mitochondrial levels of several enzymes such as acyl-CoA dehydrogenase, hydroxyacyl-CoA dehydrogenase, and $\delta(3,5)-\delta(2,4)$ dienoyl-CoA isomerase that are involved in the $\beta$-oxidation of fatty acids [51] (Figure 4).

\section{Exercise and Autophagy}

Autophagy or autophagocytosis is a universal, dynamic process that takes place in all eukaryotic cells and helps to maintain a balance between the synthesis, degradation and subsequent recycling of cellular products. This process consists of three phases: (a) formation and engulfment of the target by a double-membrane vesicle called an autophagosome, (b) delivery of autophagosomes to lysosomes, and (c) degradation of the autophagosomes and its content by lysosomal proteases [155]. Autophagy plays an important role in the basal turnover of intracellular proteins and organelles and production of amino acids in nutrient emergency. These functions guarantee rejuvenation and adaptation to changing or adverse conditions and even underlie dynamic processes such as development or metamorphosis. The autophagic pathway is crucial for maintaining cell homeostasis and disruption to the pathway can be a contributing factor to many diseases. During nutrient starvation, increased levels of autophagy lead to breakdown of nonvital components and the release of nutrients, ensuring that vital processes can continue. Mutant yeast cells that have a reduced autophagic capability rapidly perish in nutrition deficient conditions [156]. In brief, autophagy is a mechanism by which cells, in times of nutrient shortage, can degrade protein for metabolic needs and simultaneously eliminate unwanted, damaged, or redundant cell membranes and organelles including mitochondria, endoplasmic reticulum, and peroxisomes; in this regard, autophagy contrasts with the accumulation of damaged cells that naturally occurs during the process of aging. Decreased autophagy can promote the development of cancer [157] and neurodegenerative conditions including Alzheimer's [158] and Parkinson's disease [159]. In the heart, autophagy can protect against apoptosis activated by ischemic injury [160], and its chronic perturbation is causative in genetic forms of heart disease [161]. Conversely, autophagy can also be a form of programmed cell death linked to, but distinct from, apoptosis $[162,163]$.

The inductive effect of caloric restriction and suppression of autophagy by excessive caloric intake can also play roles 


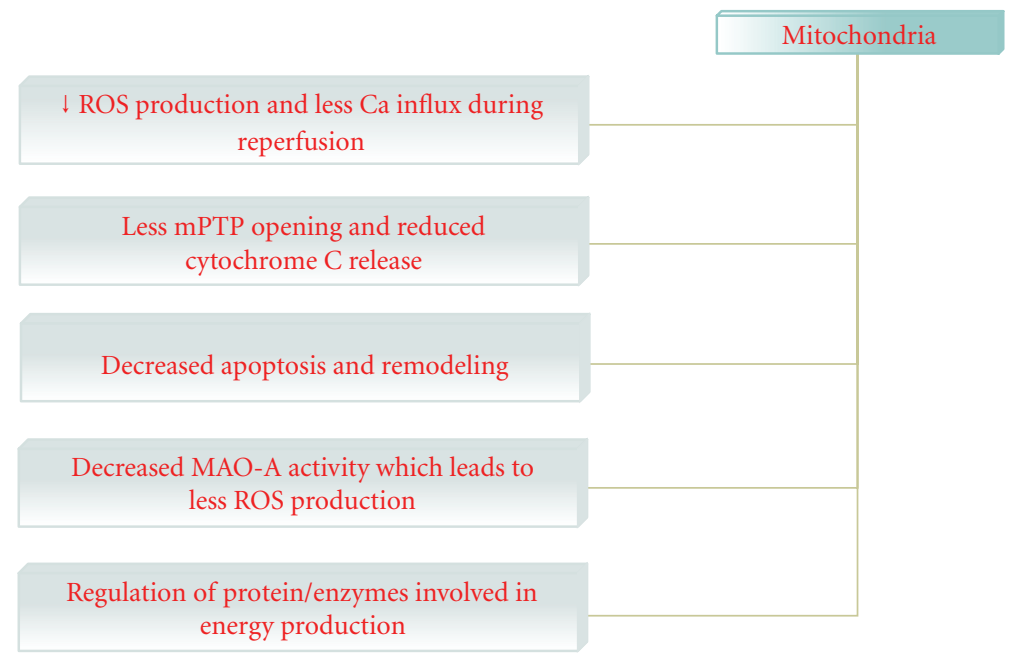

FIGURE 4: selected exercise-induced mitochondrial change in cardiac muscles. (Mitochondrial permeability transition pore, mPTP).

in the metabolic syndrome, type II diabetes, and aging $[164,165]$.

We conclude that exercise mediates its cardioprotective effects, in part, by induction and up regulation of autophagy [166-169]. Exercise-induced autophagic responses are diminished in people with the metabolic syndrome, type II diabetes, or sedentary life styles. Agents known to induce pharmacological conditioning, such as adenosine and diazoxide, are also inducers of autophagy [170]. Autophagy is upregulated in the chronically ischemic myocardium, where there is an inverse relationship with the extent of apoptosis [171]. Myocardial protection elicited by adaptation to ischemia is mediated at least in part via upregulation of autophagy $[160,172]$.

\section{Summary}

There is firm evidence from observational and randomized trials that regular exercise contributes to the primary, secondary and tertiary prevention of cardiovascular and several other lifestyle-dependent diseases and that regular exercise is associated with a reduced risk of premature death. The detailed molecular mechanisms behind this favorable effect remain unknown and continue to be actively investigated at various levels although there is significant evidence favoring redox homeostasis during cardioprotection. For the sake of clarity, we propose to divide the potential mechanisms into two major categories: those mechanisms that mainly decrease ROS production and other mechanisms that are more effective in repair and housekeeping (Table 3). These molecular adaptations lead to better physiological function and enhanced resistance to oxidative stress.

Among the proposed mechanisms for exercise-induced cardioprotection, changes in mitochondrial function and sarco $\mathrm{K}_{\text {ATP }}$ channel regulation play more significant roles. Indeed, mitochondria are important determinants of survival in cardiac myocytes exposed to I/R $[173,174]$. Therefore, its adaptations during exercise can have a greater
Table 3: Proposed mechanisms in exercise-induced cardioprotection.
Mechanisms which mainly decrease
Mechanisms which mainly ROS production repair cellular damages
(i) Sarco $\mathrm{K}_{\mathrm{ATP}}$ channles (and possibly mito $K_{\text {ATP }}$ channles)
(ii) $\uparrow \mathrm{NO}$
(iii) Mitochondrial adaptations,
(i) HSPs
(ii) $\uparrow$ Autophagy
(iii) $\uparrow$ ER stress proteins including $\uparrow \mathrm{MnSOD}$

impact on cardiac muscles. Just as important is the protective role of NO, which in addition to matching blood flow to metabolic demands also has antiatherosclerotic properties (inhibits inflammatory cells and platelets from adhering to the vascular walls) and can increase the expression of HSP70 and activate $K_{\text {ATP }}$ channels. It seems likely that other unknown cardioprotective mediators also exist and may contribute to exercise preconditioning, stressing the need for additional research to determine how the integration of the different pathways can lead to cardioprotection. Another important consideration is to better understand the impact of different exercise protocols (type, duration, and intensity) and gender differences on the time course and extent of exercise-induced cardioprotection, as this will have implications for both ongoing preventative health care as well as for developing therapeutic strategies, for example, in the management of some patients with cardiac diseases.

\section{References}

[1] F. Sofi, A. Capalbo, F. Cesari, R. Abbate, and G. F. Gensini, "Physical activity during leisure time and primary prevention of coronary heart disease: an updated meta-analysis of cohort studies," European Journal of Cardiovascular Prevention and Rehabilitation, vol. 15, no. 3, pp. 247-257, 2008. 
[2] J. A. Berlin and G. A. Colditz, "A meta-analysis of physical activity in the prevention of coronary heart disease," American Journal of Epidemiology, vol. 132, no. 4, pp. 612-628, 1990.

[3] M. Nocon, T. Hiemann, F. Müller-Riemenschneider, F. Thalau, S. Roll, and S. N. Willich, "Association of physical activity with all-cause and cardiovascular mortality: a systematic review and meta-analysis," European Journal of Cardiovascular Prevention and Rehabilitation, vol. 15, no. 3, pp. 239-246, 2008.

[4] J. Myers, M. Prakash, V. Froelicher, D. Do, S. Partington, and J. Edwin Atwood, "Exercise capacity and mortality among men referred for exercise testing," The New England Journal of Medicine, vol. 346, no. 11, pp. 793-801, 2002.

[5] P. Kokkinos, J. Myers, C. Faselis et al., "Exercise capacity and mortality in older men: a 20-year follow-up study," Circulation, vol. 122, no. 8, pp. 790-797, 2010.

[6] P. Kokkinos, M. Doumas, J. Myers et al., "A graded association of exercise capacity and all-cause mortality in males with high-normal blood pressure," Blood Pressure, vol. 18, no. 5, pp. 261-267, 2009.

[7] S. Ghosh, S. Golbidi, I. Werner, B. C. Verchere, and I. Laher, "Selecting exercise regimens and strains to modify obesity and diabetes in rodents: an overview," Clinical Science, vol. 119, no. 2, pp. 57-74, 2010.

[8] N. Yamashita, S. Hoshida, K. Otsu, M. Asahi, T. Kuzuya, and M. Hori, "Exercise provides direct biphasic cardioprotection via manganese superoxide dismutase activation," Journal of Experimental Medicine, vol. 189, no. 11, pp. 1699-1706, 1999.

[9] S. L. Lennon, J. C. Quindry, K. L. Hamilton et al., "Elevated MnSOD is not required for exercise-induced cardioprotection against myocardial stunning," American Journal of Physiology, vol. 287, no. 2, pp. H975-H980, 2004.

[10] S. L. Lennon, J. Quindry, K. L. Hamilton et al., "Loss of exercise-induced cardioprotection after cessation of exercise," Journal of Applied Physiology, vol. 96, no. 4, pp. 1299-1305, 2004.

[11] Z. Paroo, J. V. Haist, M. Karmazyn, and E. G. Noble, "Exercise improves postischemic cardiac function in males but not females: consequences of a novel sex-specific heat shock protein 70 response," Circulation Research, vol. 90, no. 8, pp. 911-917, 2002.

[12] H. Selye, "A syndrome produced by diverse nocuous agents," Journal of Neuropsychiatry and Clinical Neurosciences, vol. 10, no. 2, pp. 230-231, 1998.

[13] M. S. Marber, R. Mestril, S. H. Chi, M. R. Sayen, D. M. Yellon, and W. H. Dillmann, "Overexpression of the rat inducible $70-\mathrm{kD}$ heat stress protein in a transgenic mouse increases the resistance of the heart to ischemic injury," Journal of Clinical Investigation, vol. 95, no. 4, pp. 1446-1456, 1995.

[14] S. D. Guttman, C. V. C. Glover, C. D. Allis, and M. A. Gorovsky, "Heat shock, deciliation and release from anoxia induce the synthesis of the same set of polypeptides in starved T. pyriformis," Cell, vol. 22, no. 1, pp. 299-307, 1980.

[15] G. Weitzel, U. Pilatus, and L. Rensing, "Similar dose response of heat shock protein synthesis and intracellular $\mathrm{pH}$ change in yeast," Experimental Cell Research, vol. 159, no. 1, pp. 252256, 1985.

[16] C. Adrie, C. Richter, M. Bachelet et al., "Contrasting effects of $\mathrm{NO}$ and peroxynitrites on HSP70 expression and apoptosis in human monocytes," American Journal of Physiology, vol. 279, no. 2, pp. C452-C460, 2000.
[17] H. L. Chiang, S. R. Terlecky, C. P. Plant, and J. F. Dice, "A role for a 70-kilodaton heat shock protein in lysosomal degradation of intracellular proteins," Science, vol. 246, no. 4928, pp. 382-385, 1989.

[18] W. J. Welch, J. I. Garrels, G. P. Thomas, J. J. Lin, and J. R. Feramisco, "Biochemical characterization of the mammalian stress proteins and identification of two stress proteins as glucose- and $\mathrm{Ca}^{2+}$-ionophore-regulated proteins," The Journal of Biological Chemistry, vol. 258, no. 11, pp. 71027111, 1983.

[19] J. J. Sciandra and J. R. Subjeck, "The effects of glucose on protein synthesis and thermosensitivity in Chinese hamster ovary cells," The Journal of Biological Chemistry, vol. 258, no. 20, pp. 12091-12093, 1983.

[20] M. Locke, "The cellular stress response to exercise: role of stress proteins," Exercise and Sport Sciences Reviews, vol. 25, pp. 105-136, 1997.

[21] M. Locke, E. G. Noble, R. M. Tanguay, M. R. Feild, S. E. Ianuzzo, and C. D. Ianuzzo, "Activation of heat-shock transcription factor in rat heart after heat shock and exercise," American Journal of Physiology, vol. 268, no. 6, pp. C1387C1394, 1995.

[22] S. K. Powers, M. Locke, and H. A. Demirel, "Exercise, heat shock proteins, and myocardial protection from I-R injury," Medicine and Science in Sports and Exercise, vol. 33, no. 3, pp. 386-392, 2001.

[23] D. S. Latchman, "Heat shock proteins and cardiac protection," Cardiovascular Research, vol. 51, no. 4, pp. 637-646, 2001.

[24] I. A. Sammut and J. C. Harrison, "Cardiac mitochondrial complex activity is enhanced by heat shock proteins," Clinical and Experimental Pharmacology and Physiology, vol. 30, no. 1-2, pp. 110-115, 2003.

[25] J. Jayakumar, K. Suzuki, I. A. Sammut et al., "Heat shock protein 70 gene transfection protects mitochondrial and ventricular function against ischemia-reperfusion injury," Circulation, vol. 104, no. 1, pp. i303-i307, 2001.

[26] Z. Paroo, M. J. Meredith, M. Locke, J. V. Haist, M. Karmazyn, and E. G. Noble, "Redox signaling of cardiac HSF1 DNA binding," American Journal of Physiology, vol. 283, no. 2, pp. C404-C411, 2002.

[27] C. W. Melling, D. B. Thorp, and E. G. Noble, "Regulation of myocardial heat shock protein 70 gene expression following exercise," Journal of Molecular and Cellular Cardiology, vol. 37, no. 4, pp. 847-855, 2004.

[28] C. W. J. Melling, D. B. Thorp, K. J. Milne, M. P. Krause, and E. G. Noble, "Exercise-mediated regulation of Hsp70 expression following aerobic exercise training," American Journal of Physiology, vol. 293, no. 6, pp. H3692-H3698, 2007.

[29] K. Suzuki, B. Murtuza, I. A. Sammut et al., "Heat shock protein 72 enhances manganese superoxide dismutase activity during myocardial ischemia-reperfusion injury, associated with mitochondrial protection and apoptosis reduction," Circulation, vol. 106, no. 13, pp. I270-I276, 2002.

[30] J. Jayakumar, K. Suzuki, I. A. Sammut et al., "Heat shock protein 70 gene transfection protects mitochondrial and ventricular function against ischemia-reperfusion injury," Circulation, vol. 104, no. 12, supplement, pp. I303-i307, 2001.

[31] R. Steel, J. P. Doherty, K. Buzzard, N. Clemons, C. J. Hawkins, and R. L. Anderson, "Hsp72 inhibits apoptosis upstream of the mitochondria and not through interactions with Apaf1," The Journal of Biological Chemistry, vol. 279, no. 49, pp. 51490-51499, 2004. 
[32] I. J. Benjamin and D. R. McMillan, "Stress (heat shock) proteins molecular chaperones in cardiovascular biology and disease," Circulation Research, vol. 83, no. 2, pp. 117-132, 1998.

[33] R. P. Taylor, M. B. Harris, and J. W. Starnes, "Acute exercise can improve cardioprotection without increasing heat shock protein content," American Journal of Physiology, vol. 276, no. 3, pp. H1098-H1102, 1999.

[34] K. L. Hamilton, S. K. Powers, T. Sugiura et al., "Short-term exercise training can improve myocardial tolerance to $\mathrm{I} / \mathrm{R}$ without elevation in heat shock proteins," American Journal of Physiology, vol. 281, no. 3, pp. H1346-H1352, 2001.

[35] J. C. Quindry, K. L. Hamilton, J. P. French et al., "Exerciseinduced HSP-72 elevation and cardioprotection against infarct and apoptosis," Journal of Applied Physiology, vol. 103, no. 3, pp. 1056-1062, 2007.

[36] J. C. Quindry, K. L. Hamilton, J. P. French et al., "Heat shock protein 72 expression is not essential for exercise induced protection against infarction and apoptosis following ischemia reperfusion," The FASEB Journal, vol. 20, no. 4, A318 pages, 2006.

[37] D. Whitley, S. P. Goldberg, and W. D. Jordan, "Heat shock proteins: a review of the molecular chaperones," Journal of Vascular Surgery, vol. 29, no. 4, pp. 748-751, 1999.

[38] S. Golbidi and I. Laher, "Antioxidant therapy in human endocrine disorders," Medical Science Monitor, vol. 16, no. 1, pp. RA9-RA24, 2010.

[39] A. G. Cox, C. C. Winterbourn, and M. B. Hampton, "Mitochondrial peroxiredoxin involvement in antioxidant defence and redox signalling," Biochemical Journal, vol. 425, no. 2, pp. 313-325, 2010.

[40] F. Gündüz, U. K. Sentürk, O. Kuru, B. Aktekin, and M. R. Aktekin, "The effect of one year's swimming exercise on oxidant stress and antioxidant capacity in aged rats," Physiological Research, vol. 53, no. 2, pp. 171-176, 2004.

[41] K. Husain and S. M. Somani, "Interaction of exercise and adenosine receptor agonist and antagonist on rat heart antioxidant defense system," Molecular and Cellular Biochemistry, vol. 270, no. 1-2, pp. 209-214, 2005.

[42] K. L. Hamilton, J. L. Staib, T. Phillips, A. Hess, S. L. Lennon, and S. K. Powers, "Exercise, antioxidants, and HSP72: protection against myocardial ischemia/reperfusion," Free Radical Biology and Medicine, vol. 34, no. 7, pp. 800-809, 2003.

[43] H. A. Demirel, S. K. Powers, M. A. Zergeroglu et al., "Short-term exercise improves myocardial tolerance to in vivo ischemia-reperfusion in the rat," Journal of Applied Physiology, vol. 91, no. 5, pp. 2205-2212, 2001.

[44] S. L. Lennon, J. Quindry, K. L. Hamilton et al., "Loss of exercise-induced cardioprotection after cessation of exercise," Journal of Applied Physiology, vol. 96, no. 4, pp. 1299-1305, 2004.

[45] J. W. Starnes, R. P. Taylor, and Y. Park, "Exercise improves postischemic function in aging hearts," American Journal of Physiology, vol. 285, no. 1, pp. H347-H351, 2003.

[46] N. Yamashita, S. Hoshida, K. Otsu, M. Asahi, T. Kuzuya, and M. Hori, "Exercise provides direct biphasic cardioprotection via manganese superoxide dismutase activation," Journal of Experimental Medicine, vol. 189, no. 11, pp. 1699-1706, 1999.

[47] D. A. Brown, K. N. Jew, G. C. Sparagna, T. I. Musch, and R. L. Moore, "Exercise training preserves coronary flow and reduces infarct size after ischemia-reperfusion in rat heart," Journal of Applied Physiology, vol. 95, no. 6, pp. 2510-2518, 2003.
[48] J. P. French, K. L. Hamilton, J. C. Quindry, Y. Lee, P. A. Upchurch, and S. K. Powers, "Exercise-induced protection against myocardial apoptosis and necrosis: MnSOD, calcium-handling proteins, and calpain," FASEB Journal, vol. 22, no. 8, pp. 2862-2871, 2008.

[49] K. L. Hamilton, J. C. Quindry, J. P. French et al., "MnSOD antisense treatment and exercise-induced protection against arrhythmias," Free Radical Biology and Medicine, vol. 37, no. 9, pp. 1360-1368, 2004.

[50] S. L. Lennon, J. C. Quindry, K. L. Hamilton et al., "Elevated MnSOD is not required for exercise-induced cardioprotection against myocardial stunning," American Journal of Physiology, vol. 287, no. 2, pp. H975-H980, 2004.

[51] A. N. Kavazis, "Exercise preconditioning of the myocardium," Sports Medicine, vol. 39, no. 11, pp. 923935, 2009.

[52] S. K. Powers, J. C. Quindry, and A. N. Kavazis, "Exerciseinduced cardioprotection against myocardial ischemiareperfusion injury," Free Radical Biology and Medicine, vol. 44, no. 2, pp. 193-201, 2008.

[53] F. P. Leung, L. M. Yung, I. Laher, X. Yao, Z. Y. Chen, and YU. Huang, "Exercise, vascular wall and cardiovascular diseases: an update (part 1)," Sports Medicine, vol. 38, no. 12, pp. 10091024, 2008

[54] J. Rehman, J. Li, L. Parvathaneni et al., "Exercise acutely increases circulating endothelial progenitor cells and monocyte-/macrophage-derived angiogenic cells," Journal of the American College of Cardiology, vol. 43, no. 12, pp. 2314-2318, 2004.

[55] S. Steiner, A. Niessner, S. Ziegler et al., "Endurance training increases the number of endothelial progenitor cells in patients with cardiovascular risk and coronary artery disease," Atherosclerosis, vol. 181, no. 2, pp. 305-310, 2005.

[56] U. Laufs, A. Urhausen, N. Werner et al., "Running exercise of different duration and intensity: effect on endothelial progenitor cells in healthy subjects," European Journal of Cardiovascular Prevention and Rehabilitation, vol. 12, no. 4, pp. 407-414, 2005.

[57] M. S. O’Reilly, T. Boehm, Y. Shing et al., "Endostatin: an endogenous inhibitor of angiogenesis and tumor growth," Cell, vol. 88, no. 2, pp. 277-285, 1997.

[58] J. Obeso, J. Weber, and R. Auerbach, "A hemangioendothelioma-derived cell line: its use as a model for the study of endothelial cell biology," Laboratory Investigation, vol. 63, no. 2, pp. 259-269, 1990.

[59] M. Ferreras, U. Felbor, T. Lenhard, B. R. Olsen, and J. M. Delaissé, "Generation and degradation of human endostatin proteins by various proteinases," FEBS Letters, vol. 486, no. 3, pp. 247-251, 2000.

[60] J. Saarela, M. Rehn, A. Oikarinen, H. Autio-Harmainen, and T. Pihlajaniemi, "The short and long forms of type XVIII collagen show clear tissue specificities in their expression and location in basement membrane zones in humans," American Journal of Pathology, vol. 153, no. 2, pp. 611-626, 1998.

[61] M. Shichiri and Y. Hirata, "Antiangiogenesis signals by endostatin,” FASEB Journal, vol. 15, no. 6, pp. 1044-1053, 2001.

[62] L. Taddei, P. Chiarugi, L. Brogelli et al., "Inhibitory effect of full-length human endostatin on in vitro angiogenesis," Biochemical and Biophysical Research Communications, vol. 263, no. 2, pp. 340-345, 1999. 
[63] K. Eriksson, P. Magnusson, J. Dixelius, L. Claesson-Welsh, and M. J. Cross, "Angiostatin and endostatin inhibit endothelial cell migration in response to FGF and VEGF without interfering with specific intracellular signal transduction pathways," FEBS Letters, vol. 536, no. 1-3, pp. 19-24, 2003.

[64] J. M. Isner and D. W. Losordo, "Therapeutic angiogenesis for heart failure," Nature Medicine, vol. 5, no. 5, pp. 491-492, 1999.

[65] F. L. Celletti, P. R. Hilfiker, P. Ghafouri, and M. D. Dake, "Effect of human recombinant vascular endothelial growth factor on progression of atherosclerotic plaque," Journal of the American College of Cardiology, vol. 37, no. 8, pp. 21262130, 2001.

[66] K. B. Lemström, R. Krebs, A. I. Nykänen et al., "Vascular endothelial growth factor enhances cardiac allograft arteriosclerosis," Circulation, vol. 105, no. 21, pp. 2524-2530, 2002.

[67] R. S. Richardson, H. Wagner, S. R. D. Mudaliar, E. Saucedo, R. Henry, and P. D. Wagner, "Exercise adaptation attenuates VEGF gene expression in human skeletal muscle," American Journal of Physiology, vol. 279, no. 2, pp. H772-H778, 2000.

[68] J. W. Gu, G. Gadonski, J. Wang, I. Makey, and T. H. Adair, "Exercise increases endostatin in circulation of healthy volunteers," BMC Physiology, vol. 4, article 1, pp. 1-6, 2004.

[69] K. Brixius, S. Schoenberger, D. Ladage et al., "Long-term endurance exercise decreases antiangiogenic endostatin signalling in overweight men aged 50-60 years," British Journal of Sports Medicine, vol. 42, no. 2, pp. 126-129, 2008.

[70] M. D. Brown, "Exercise and coronary vascular remodelling in the healthy heart," Experimental Physiology, vol. 88, no. 5, pp. 645-658, 2003.

[71] W. L. Haskell, C. Sims, J. Myll, W. M. Bortz, F. G. St. Goar F.G., and E. L. Alderman, "Coronary artery size and dilating capacity in ultradistance runners," Circulation, vol. 87, no. 4, pp. 1076-1082, 1993.

[72] H. L. Wyatt and J. Mitchell, "Influences of physical conditioning and deconditioning on coronary vasculature of dogs," Journal of Applied Physiology, vol. 45, no. 4, pp. 619-625, 1978.

[73] R. Belardinelli, D. Georgiou, L. Ginzton, G. Cianci, and A. Purcaro, "Effects of moderate exercise training on thallium uptake and contractile response to low-dose dobutamine of dysfunctional myocardium in patients with ischemic cardiomyopathy," Circulation, vol. 97, no. 6, pp. 553-561, 1998.

[74] D. N. Sim and W. A. Neill, "Investigation of the physiological basis for increased exercise threshold for angina pectoris after physical conditioning," Journal of Clinical Investigation, vol. 54, no. 3, pp. 763-770, 1974.

[75] M. V. Cohen, C. P. Baines, and J. M. Downey, "Ischemic preconditioning: from adenosine receptor to K(ATP) channel," Annual Review of Physiology, vol. 62, pp. 79-109, 2000.

[76] R. Bolli, "The late phase of preconditioning," Circulation Research, vol. 87, no. 11, pp. 972-983, 2000.

[77] H. A. Demirel, S. K. Powers, C. Caillaud et al., "Exercise training reduces myocardial lipid peroxidation following short- term ischemia-reperfusion," Medicine and Science in Sports and Exercise, vol. 30, no. 8, pp. 1211-1216, 1998.

[78] H. A. Demirel, S. K. Powers, M. A. Zergeroglu et al., "Short-term exercise improves myocardial tolerance to in vivo ischemia-reperfusion in the rat," Journal of Applied Physiology, vol. 91, no. 5, pp. 2205-2212, 2001.
[79] R. Bolli, "Preconditioning: a paradigm shift in the biology of myocardial ischemia," American Journal of Physiology, vol. 292, no. 1, pp. H19-H27, 2007.

[80] S. Hoshida, N. Yamashita, K. Otsu, and M. Hori, "Repeated physiologic stresses provide persistent cardioprotection against ischemia-reperfusion injury in rats," Journal of the American College of Cardiology, vol. 40, no. 4, pp. 826-831, 2002.

[81] O. Nagy, A. Hajnal, J. R. Parratt, and A. Végh, "Delayed exercise-induced protection against arrhythmias in dogseffect of celecoxib," European Journal of Pharmacology, vol. 499, no. 1-2, pp. 197-199, 2004.

[82] J. C. Quindry, J. French, K. L. Hamilton, Y. Lee, J. Selsby, and S. K. Powers, "Cyclooxygenase 2 is unaltered by exercise in the young and old heart," Medicine \& Science in Sports \& Exercise, vol. 38, p. s416, 2006.

[83] J. C. Quindry, J. French, K. L. Hamilton, Y. Lee, J. Selsby, and S. Powers, "Exercise does not increase cyclooxygenase2 myocardial levels in young or senescent hearts," Journal of Physiological Sciences, vol. 60, no. 3, pp. 181-186, 2010.

[84] S. E. Logue, A. B. Gustafsson, A. Samali, and R. A. Gottlieb, "Ischemia/reperfusion injury at the intersection with cell death," Journal of Molecular and Cellular Cardiology, vol. 38, no. 1, pp. 21-33, 2005.

[85] J. Wu and R. J. Kaufman, "From acute ER stress to physiological roles of the unfolded protein response," Cell Death and Differentiation, vol. 13, no. 3, pp. 374-384, 2006.

[86] M. Vitadello, D. Penzo, V. Petronilli et al., "Overexpression of the stress protein Grp94 reduces cardiomyocyte necrosis due to calcium overload and simulated ischemia," The FASEB Journal, vol. 17, no. 8, pp. 923-925, 2003.

[87] J. J. Martindale, R. Fernandez, D. Thuerauf et al., "Endoplasmic reticulum stress gene induction and protection from ischemia/reperfusion injury in the hearts of transgenic mice with a tamoxifen-regulated form of ATF6," Circulation Research, vol. 98, no. 9, pp. 1186-1193, 2006.

[88] Z. Murlasits, Y. Lee, and S. K. Powers, "Short-term exercise does not increase ER stress protein expression in cardiac muscle," Medicine and Science in Sports and Exercise, vol. 39, no. 9, pp. 1522-1528, 2007.

[89] A. B. Stein, X. L. Tang, Y. Guo, YU. T. Xuan, B. Dawn, and R. Bolli, "Delayed adaptation of the heart to stress: late preconditioning," Stroke, vol. 35, no. 11, pp. 2676-2679, 2004.

[90] P. F. Méry, C. Pavoine, L. Belhassen, F. Pecker, and R. Fischmeister, "Nitric oxide regulates cardiac $\mathrm{Ca}^{2+}$ current. Involvement of cGMP- inhibited and cGMP-stimulated phosphodiesterases through guanylyl cyclase activation," The Journal of Biological Chemistry, vol. 268, no. 35, pp. 2628626295, 1993.

[91] J. L. Balligand, R. A. Kelly, P. A. Marsden, T. W. Smith, and T. Michel, "Control of cardiac muscle cell function by an endogenous nitric oxide signaling system," Proceedings of the National Academy of Sciences of the United States of America, vol. 90, no. 1, pp. 347-351, 1993.

[92] W. Shen, T. H. Hintze, and M. S. Wolin, "Nitric oxide: an important signaling mechanism between vascular endothelium and parenchymal cells in the regulation of oxygen consumption," Circulation, vol. 92, no. 12, pp. 3505-3512, 1995.

[93] Y. W. Xie, W. Shen, G. Zhao, X. Xu, M. S. Wolin, and T. H. Hintze, "Role of endothelium-derived nitric oxide in the modulation of canine myocardial mitochondrial respiration 
in vitro: implications for the development of heart failure," Circulation Research, vol. 79, no. 3, pp. 381-387, 1996.

[94] A. Shinbo and T. Iijima, "Potentiation by nitric oxide of the ATP-sensitive $\mathrm{K}^{+}$current induced by $\mathrm{K}^{+}$channel openers in guinea-pig ventricular cells," British Journal of Pharmacology, vol. 120, no. 8, pp. 1568-1574, 1997.

[95] R. Hambrecht, V. Adams, S. Erbs et al., "Regular physical activity improves endothelial function in patients with coronary artery disease by increasing phosphorylation of endothelial nitric oxide synthase," Circulation, vol. 107, no. 25, pp. 3152-3158, 2003.

[96] D. J. Green, A. Maiorana, G. O’Driscoll, and R. Taylor, "Effect of exercise training on endothelium-derived nitric oxide function in humans," Journal of Physiology, vol. 561, no. 1, pp. 1-25, 2004.

[97] C. Le Page, P. Noirez, J. Courty, B. Riou, B. Swynghedauw, and S. Besse, "Exercise training improves functional postischemic recovery in senescent heart," Experimental Gerontology, vol. 44, no. 3, pp. 177-182, 2009.

[98] B. A. Kingwell, "Nitric oxide as a metabolic regulator during exercise: effects of training in health and disease," Clinical and Experimental Pharmacology and Physiology, vol. 27, no. 4, pp. 239-250, 2000.

[99] K. E. Loke, S. K. Laycock, S. Mital et al., "Nitric oxide modulates mitochondrial respiration in failing human heart," Circulation, vol. 100, no. 12, pp. 1291-1297, 1999.

[100] Y. M. Kim, R. V. Talanian, and T. R. Billiar, "Nitric oxide inhibits apoptosis by preventing increases in caspase-3like activity via two distinct mechanisms," The Journal of Biological Chemistry, vol. 272, no. 49, pp. 31138-31148, 1997.

[101] L. Babai, Z. Szigeti, J. R. Parratt, and A. Végh, "Delayed cardioprotective effects of exercise in dogs are aminoguanidine sensitive: possible involvement of nitric oxide," Clinical Science, vol. 102, no. 4, pp. 435-445, 2002.

[102] I. Momken, P. Lechêne, R. Ventura-Clapier, and V. Veksler, "Voluntary physical activity alterations in endothelial nitric oxide synthase knockout mice," American Journal of Physiology, vol. 287, no. 2, pp. H914-H920, 2004.

[103] C. Ojaimi, W. Li, S. Kinugawa et al., "Transcriptional basis for exercise limitation in male eNOS-knockout mice with age: heart failure and the fetal phenotype," American Journal of Physiology, vol. 289, no. 4, pp. H1399-H1407, 2005.

[104] M. C. de Waard, R. van Haperen, T. Soullié, D. Tempel, R. de Crom, and D. J. Duncker, "Beneficial effects of exercise training after myocardial infarction require full eNOS expression," Journal of Molecular and Cellular Cardiology, vol. 48, no. 6, pp. 1041-1049, 2010.

[105] R. P. Taylor, M. E. Olsen, and J. W. Starnes, "Improved postischemic function following acute exercise is not mediated by nitric oxide synthase in the rat heart," American Journal of Physiology, vol. 292, no. 1, pp. H601-H607, 2007.

[106] D. J. Lefer, "Nitrite therapy for protection against ischemiareperfusion injury," American Journal of Physiology, vol. 290, no. 4, pp. F777-F778, 2006.

[107] J. L. Zweier, P. Wang, A. Samouilov, and P. Kuppusamy, "Enzyme-independent formation of nitric oxide in biological tissues," Nature Medicine, vol. 1, no. 8, pp. 804-809, 1995.

[108] A. Webb, R. Bond, P. McLean, R. Uppal, N. Benjamin, and A. Ahluwalia, "Reduction of nitrite to nitric oxide during ischemia protects against myocardial ischemia-reperfusion damage," Proceedings of the National Academy of Sciences of the United States of America, vol. 101, no. 37, pp. 1368313688, 2004.
[109] M. R. Duranski, J. J. M. Greer, A. Dejam et al., "Cytoprotective effects of nitrite during in vivo ischemia-reperfusion of the heart and liver," Journal of Clinical Investigation, vol. 115, no. 5, pp. 1232-1240, 2005.

[110] Y. Zhang, T. S. Lee, E. M. Kolb et al., "AMP-activated protein kinase is involved in endothelial NO synthase activation in response to shear stress," Arteriosclerosis, Thrombosis, and Vascular Biology, vol. 26, no. 6, pp. 1281-1287, 2006.

[111] C. Napoli, S. Williams-Ignarro, F. De Nigris et al., "Physical training and metabolic supplementation reduce spontaneous atherosclerotic plaque rupture and prolong survival in hypercholesterolemic mice," Proceedings of the National Academy of Sciences of the United States of America, vol. 103, no. 27, pp. 10479-10484, 2006.

[112] J. W. Calvert, "Cardioprotective effects of nitrite during exercise," Cardiovascular Research, vol. 89, no. 3, pp. 499-506, 2011.

[113] J. W. Starnes and R. P. Taylor, "Exercise-induced cardioprotection: endogenous mechanisms," Medicine and Science in Sports and Exercise, vol. 39, no. 9, pp. 1537-1543, 2007.

[114] J. E. Baker, S. J. Contney, R. Singh, B. Kalyanaraman, G. J. Gross, and Z. J. Bosnjak, "Nitric oxide activates the sarcolemmal Kchannel in normoxic and chronically hypoxic hearts by a cyclic GMP-dependent mechanism," Journal of Molecular and Cellular Cardiology, vol. 33, no. 2, pp. 331-341, 2001.

[115] D. V. Cuong, N. Kim, J. B. Youm et al., "Nitric oxidecGMP-protein kinase $G$ signaling pathway induces anoxic preconditioning through activation of ATP-sensitive $\mathrm{K}^{+}$ channels in rat hearts," American Journal of Physiology, vol. 290, no. 5, pp. H1808-H1817, 2006.

[116] Q. Xu, Y. Hu, R. Kleindienst, and G. Wick, "Nitric oxide induces heat-shock protein 70 expression in vascular smooth muscle cells via activation of heat shock factor 1," Journal of Clinical Investigation, vol. 100, no. 5, pp. 1089-1097, 1997.

[117] A. Noma, "ATP-regulated K channels in cardiac muscle," Nature, vol. 305, no. 5930, pp. 147-148, 1983.

[118] Y. V. Ladilov, B. Siegmund, and H. M. Piper, "Protection of reoxygenated cardiomyocytes against hypercontracture by inhibition of $\mathrm{Na}^{+} / \mathrm{H}^{+}$exchange," American Journal of Physiology, vol. 268, no. 4, pp. H1531-H1539, 1995.

[119] H. M. Piper, Y. Abdallah, and C. Schäfer, "The first minutes of reperfusion: a window of opportunity for cardioprotection," Cardiovascular Research, vol. 61, no. 3, pp. 365-371, 2004.

[120] J. Inserte, D. Garcia-Dorado, V. Hernando, and J. Soler-Soler, "Calpain-mediated impairment of $\mathrm{Na}^{+} / \mathrm{K}^{+}$-ATPase activity during early reperfusion contributes to cell death after myocardial ischemia," Circulation Research, vol. 97, no. 5, pp. 465-473, 2005.

[121] W. J. Nelson and R. W. Hammerton, "A membranecytoskeletal complex containing $\mathrm{Na}^{+}, \mathrm{K}^{+}$-ATPase, ankyrin, and fodrin in Madin-Darby canine kidney (MDCK) cells: implications for the biogenesis of epithelial cell polarity," Journal of Cell Biology, vol. 108, no. 3, pp. 893-902, 1989.

[122] A. Skyschally, R. Schulz, and G. Heusch, "Pathophysiology of myocardial infarction. Protection by ischemic pre- and postconditioning," Herz, vol. 33, no. 2, pp. 88-100, 2008.

[123] A. P. Halestrap, "Calcium, mitochondria and reperfusion injury: a pore way to die," Biochemical Society Transactions, vol. 34, no. 2, pp. 232-237, 2006.

[124] W. C. Cole, C. D. McPherson, and D. Sontag, "ATPregulated $\mathrm{K}^{+}$channels protect the myocardium against ischemia/reperfusion damage," Circulation Research, vol. 69, no. 3, pp. 571-581, 1991. 
[125] H. L. Tan, P. Mazón, H. J. Verberne et al., "Ischaemic preconditioning delays ischaemia induced cellular electrical uncoupling in rabbit myocardium by activation of ATP sensitive potassium channels," Cardiovascular Research, vol. 27, no. 4, pp. 644-651, 1993.

[126] Z. Yao and G. J. Gross, "Activation of ATP-sensitive potassium channels lowers threshold for ischemic preconditioning in dogs," American Journal of Physiology, vol. 267, no. 5, pp. H1888-H1894, 1994.

[127] Z. Yao and G. J. Gross, "Effects of the $K_{\text {ATP }}$ channel opener bimakalim on coronary blood flow, monophasic action potential duration, and infarct size in dogs," Circulation, vol. 89, no. 4, pp. 1769-1775, 1994.

[128] D. A. Brown, A. J. Chicco, K. N. Jew et al., "Cardioprotection afforded by chronic exercise is mediated by the sarcolemmal, and not the mitochondrial, isoform of the $\mathrm{K}_{\mathrm{ATP}}$ channel in the rat," Journal of Physiology, vol. 569, no. 3, pp. 913-924, 2005.

[129] A. J. Chicco, M. S. Johnson, C. J. Armstrong et al., "Sexspecific and exercise-acquired cardioprotection is abolished by sarcolemmal $\mathrm{K}_{\mathrm{ATP}}$ channel blockade in the rat heart," American Journal of Physiology, vol. 292, no. 5, pp. H2432H2437, 2007.

[130] D. A. Brown, J. M. Lynch, C. J. Armstrong et al., "Susceptibility of the heart to ischaemia-reperfusion injury and exercise-induced cardioprotection are sex-dependent in the rat," Journal of Physiology, vol. 564, no. 2, pp. 619-630, 2005.

[131] H. J. Ranki, G. R. Budas, R. M. Crawford, A. M. Davies, and A. Jovanović, " $17 \beta$-estradiol regulates expression of $\mathrm{K}_{\mathrm{ATP}}$ channels in heart-derived H9c2 cells," Journal of the American College of Cardiology, vol. 40, no. 2, pp. 367-374, 2002.

[132] M. S. Johnson, R. L. Moore, and D. A. Brown, "Sex differences in myocardial infarct size are abolished by sarcolemmal $\mathrm{K}_{\text {ATP }}$ channel blockade in rat," American Journal of Physiology, vol. 290, no. 6, pp. H2644-H2647, 2006.

[133] A. J. Chicco, M. S. Johnson, C. J. Armstrong et al., "Sexspecific and exercise-acquired cardioprotection is abolished by sarcolemmal $\mathrm{K}_{\mathrm{ATP}}$ channel blockade in the rat heart," American Journal of Physiology, vol. 292, no. 5, pp. H2432H2437, 2007.

[134] S. Bae and L. Zhang, "Gender differences in cardioprotection against ischemia/reperfusion injury in adult rat hearts: focus on akt and protein kinase C signaling," Journal of Pharmacology and Experimental Therapeutics, vol. 315, no. 3, pp. 1125-1135, 2005.

[135] A. G. Edwards, M. L. Rees, R. A. Gioscia et al., "PKCpermitted elevation of sarcolemmal $\mathrm{K}_{\mathrm{ATP}}$ concentration may explain female-specific resistance to myocardial infarction," Journal of Physiology, vol. 587, no. 23, pp. 5723-5737, 2009.

[136] K. Hu, C. S. Huang, Y. N. Jan, and L. Y. Jan, "ATPsensitive potassium channel traffic regulation by adenosine and protein kinase C," Neuron, vol. 38, no. 3, pp. 417-432, 2003.

[137] A. Jovanović, "Femininity and sarcolemmal $\mathrm{K}_{\mathrm{ATP}}$ channels: a matter of the heart and the heart of the matter," Journal of Physiology, vol. 587, no. 23, pp. 5509-5510, 2009.

[138] G. J. Gross and J. N. Peart, " $\mathrm{K}_{\text {ATP }}$ channels and myocardial preconditioning: an update," American Journal of Physiology, vol. 285, no. 3, pp. H921-H930, 2003.

[139] X. Kong, J. S. Tweddell, G. J. Gross, and J. E. Baker, "Sarcolemmal and mitochondrial $\mathrm{K}_{\text {ATP }}$ channels mediate cardioprotection in chronically hypoxic hearts," Journal of Molecular and Cellular Cardiology, vol. 33, no. 5, pp. 10411045, 2001.
[140] R. M. Fryer, A. K. Hsu, and G. J. Gross, "Mitochondrial K ATP $_{\text {at }}$ channel opening is important during index ischemia and following myocardial reperfusion in ischemic preconditioned rat hearts," Journal of Molecular and Cellular Cardiology, vol. 33, no. 4, pp. 831-834, 2001.

[141] K. Shinmura, K. Tamaki, T. Sato, H. Ishida, and R. Bolli, "Prostacyclin attenuates oxidative damage of myocytes by opening mitochondrial ATP-sensitive $\mathrm{K}^{+}$channels via the $\mathrm{EP}_{3}$ receptor," American Journal of Physiology, vol. 288, no. 5, pp. H2093-H2101, 2005.

[142] R. Domenech, P. Macho, H. Schwarze, and G. Sánchez, "Exercise induces early and late myocardial preconditioning in dogs," Cardiovascular Research, vol. 55, no. 3, pp. 561-566, 2002.

[143] J. C. Quindry, L. Schreiber, P. Hosick, J. Wrieden, J. M. Irwin, and E. Hoyt, "Mitochondrial $\mathrm{K}_{\mathrm{ATP}}$ channel inhibition blunts arrhythmia protection in ischemic exercised hearts," American Journal of Physiology, vol. 299, no. 1, pp. H175H183, 2010.

[144] S. Judge, Y. M. Jang, A. Smith et al., "Exercise by lifelong voluntary wheel running reduces subsarcolemmal and interfibrillar mitochondrial hydrogen peroxide production in the heart," American Journal of Physiology, vol. 289, no. 6, pp. R1564-R1572, 2005.

[145] J. W. Starnes, B. D. Barnes, and M. E. Olsen, "Exercise training decreases rat heart mitochondria free radical generation but does not prevent $\mathrm{Ca}^{2+}$-induced dysfunction," Journal of Applied Physiology, vol. 102, no. 5, pp. 1793-1798, 2007.

[146] M. Marcil, K. Bourduas, A. Ascah, and Y. Burelle, "Exercise training induces respiratory substrate-specific decrease in $\mathrm{Ca}^{2+}$-induced permeability transition pore opening in heart mitochondria," American Journal of Physiology, vol. 290, no. 4, pp. H1549-H1557, 2006.

[147] A. N. Kavazis, J. M. McClung, D. A. Hood, and S. K. Powers, "Exercise induces a cardiac mitochondrial phenotype that resists apoptotic stimuli," American Journal of Physiology, vol. 294, no. 2, pp. H928-H935, 2008.

[148] S. Ghosh, M. Khazaei, F. Moien-Afshari et al., "Moderate exercise attenuates caspase- 3 activity, oxidative stress, and inhibits progression of diabetic renal disease in $\mathrm{db} / \mathrm{db}$ mice," American Journal of Physiology, vol. 296, no. 4, pp. F700F708, 2009.

[149] M. B. H. Youdim and J. P. M. Finberg, "New directions in monoamine oxidase A and B: selective inhibitors and substrates," Biochemical Pharmacology, vol. 41, no. 2, pp. 155-162, 1991.

[150] A. Maurel, C. Hernandez, O. Kunduzova et al., "Agedependent increase in hydrogen peroxide production by cardiac monoamine oxidase A in rats," American Journal of Physiology, vol. 284, no. 4, pp. H1460-H1467, 2003.

[151] S. W. Kong, N. Bodyak, P. Yue et al., "Genetic expression profiles during physiological and pathological cardiac hypertrophy and heart failure in rats," Physiological Genomics, vol. 21, pp. 34-42, 2005.

[152] P. Bianchi, O. Kunduzova, E. Masini et al., "Oxidative stress by monoamine oxidase mediates receptor-independent cardiomyocyte apoptosis by serotonin and postischemic myocardial injury," Circulation, vol. 112, no. 21, pp. 32973305, 2005.

[153] D. Pchejetski, O. Kunduzova, A. Dayon et al., "Oxidative stress-dependent sphingosine kinase-1 inhibition mediates monoamine oxidase A-associated cardiac cell apoptosis," Circulation Research, vol. 100, no. 1, pp. 41-49, 2007. 
[154] A. N. Kavazis, S. Alvarez, E. Talbert, Y. Lee, and S. K. Powers, "Exercise training induces a cardioprotective phenotype and alterations in cardiac subsarcolemmal and intermyofibrillar mitochondrial proteins," American Journal of Physiology, vol. 297, no. 1, pp. H144-H152, 2009.

[155] N. R. Brady, A. Hamacher-Brady, H. Yuan, and R. A. Gottlieb, "The autophagic response to nutrient deprivation in the hl-1 cardiac myocyte is modulated by Bcl-2 and sarco/endoplasmic reticulum calcium stores," FEBS Journal, vol. 274, no. 12, pp. 3184-3197, 2007.

[156] M. Tsukada and Y. Ohsumi, "Isolation and characterization of autophagy-defective mutants of Saccharomyces cerevisiae," FEBS Letters, vol. 333, no. 1-2, pp. 169-174, 1993.

[157] Z. Yue, S. Jin, C. Yang, A. J. Levine, and N. Heintz, "Beclin 1 , an autophagy gene essential for early embryonic development, is a haploinsufficient tumor suppressor," Proceedings of the National Academy of Sciences of the United States of America, vol. 100, no. 25, pp. 15077-15082, 2003.

[158] R. A. Nixon, J. Wegiel, A. Kumar et al., "Extensive involvement of autophagy in Alzheimer disease: an immunoelectron microscopy study," Journal of Neuropathology and Experimental Neurology, vol. 64, no. 2, pp. 113-122, 2005.

[159] J. L. Webb, B. Ravikumar, J. Atkins, J. N. Skepper, and D. C. Rubinsztein, " $\alpha$-Synuclein is degraded by both autophagy and the proteasome," The Journal of Biological Chemistry, vol. 278, no. 27, pp. 25009-25013, 2003.

[160] L. Yan, D. E. Vatner, S. J. Kim et al., "Autophagy in chronically ischemic myocardium," Proceedings of the National Academy of Sciences of the United States of America, vol. 102, no. 39, pp. 13807-13812, 2005.

[161] P. Saftig, K. Von Figura, Y. Tanaka, and R. Lüllmann-Rauch, "Disease model: LAMP-2 enlightens Danon disease," Trends in Molecular Medicine, vol. 7, no. 1, pp. 37-39, 2000.

[162] L. Xue, G. C. Fletcher, and A. M. Tolkovsky, "Mitochondria are selectively eliminated from eukaryotic cells after blockade of caspases during apoptosis," Current Biology, vol. 11, no. 5, pp. 361-365, 2001.

[163] S. Shimizu, T. Kanaseki, N. Mizushima et al., "Role of Bcl-2 family proteins in a non-apoptopic programmed cell death dependent on autophagy genes," Nature Cell Biology, vol. 6, no. 12, pp. 1221-1228, 2004.

[164] W. Dröge and H. M. Schipper, "Oxidative stress and aberrant signaling in aging and cognitive decline," Aging Cell, vol. 6, no. 3, pp. 361-370, 2007.

[165] G. J. Etgen, B. A. Oldham, W. T. Johnson et al., "A tailored therapy for the metabolic syndrome: the dual peroxisome proliferator-activated receptor- $\alpha / \gamma$ agonist LY465608 ameliorates insulin resistance and diabetic hyperglycemia while improving cardiovascular risk factors in preclinical models," Diabetes, vol. 51, no. 4, pp. 1083-1087, 2002.

[166] G. L. Dohm, E. B. Tapscott, and G. J. Kasperek, "Protein degradation during endurance exercise and recovery," Medicine and Science in Sports and Exercise, vol. 19, no. 5, pp. S166-171, 1987.

[167] J. P. French, K. L. Hamilton, J. C. Quindry, Y. Lee, P. A. Upchurch, and S. K. Powers, "Exercise-induced protection against myocardial apoptosis and necrosis: MnSOD, calcium-handling proteins, and calpain," FASEB Journal, vol. 22, no. 8, pp. 2862-2871, 2008.

[168] A. Kawai, H. Uchiyama, S. Takano, N. Nakamura, and S. Ohkuma, "Autophagosome-lysosome fusion depends on the pH in acidic compartments in CHO cells," Autophagy, vol. 3, no. 2, pp. 154-157, 2007.
[169] M. G. MacKenzie, D. L. Hamilton, J. T. Murray, and K. Baar, "mVps34 is activated by an acute bout of resistance exercise," Biochemical Society Transactions, vol. 35, no. 5, pp. 13141316, 2007.

[170] D. K. Arrell, S. T. Elliott, L. A. Kane et al., "Proteomic analysis of pharmacological preconditioning: novel protein targets converge to mitochondrial metabolism pathways," Circulation Research, vol. 99, no. 7, pp. 706-714, 2006.

[171] M. G. Mackenzie, D. L. Hamilton, J. T. Murray, P. M. Taylor, and K. Baar, "mVps34 is activated following high-resistance contractions," Journal of Physiology, vol. 587, no. 1, pp. 253260, 2009.

[172] N. Gurusamy, I. Lekli, N. V. Gorbunov, M. Gherghiceanu, L. M. Popescu, and D. K. Das, "Cardioprotection by adaptation to ischaemia augments autophagy in association with BAG-1 protein," Journal of Cellular and Molecular Medicine, vol. 13, no. 2, pp. 373-387, 2009.

[173] B. O'Rourke, S. Cortassa, and M. A. Aon, "Mitochondrial ion channels: gatekeepers of life and death," Physiology, vol. 20, no. 5, pp. 303-315, 2005.

[174] H. M. Honda, P. Korge, and J. N. Weiss, "Mitochondria and ischemia/reperfusion injury," Annals of the New York Academy of Sciences, vol. 1047, pp. 248-258, 2005. 


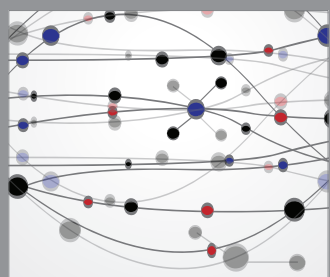

The Scientific World Journal
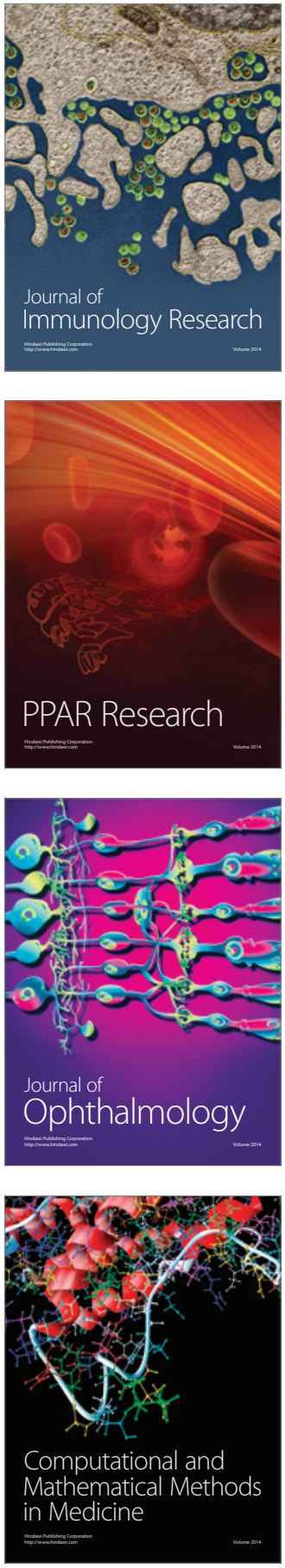

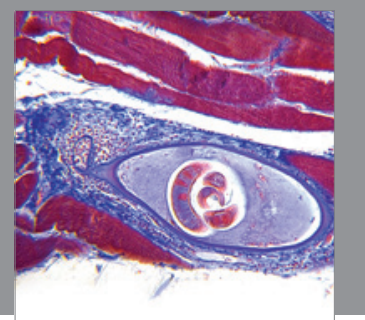

Gastroenterology

Research and Practice
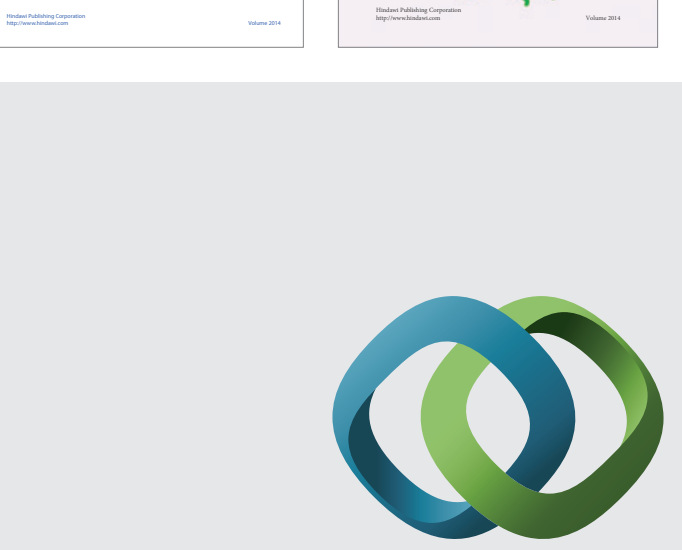

\section{Hindawi}

Submit your manuscripts at

http://www.hindawi.com
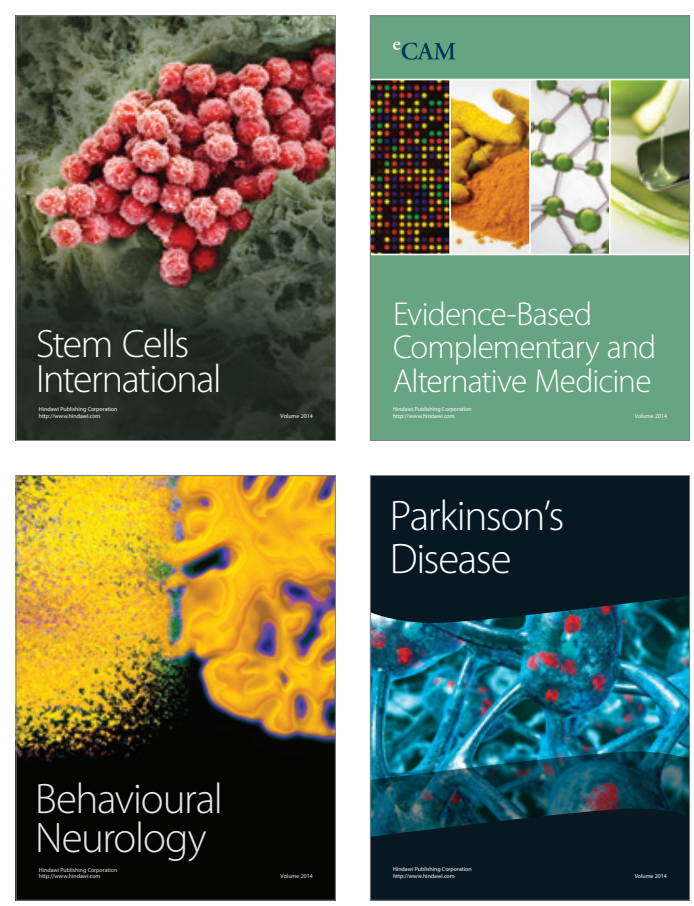

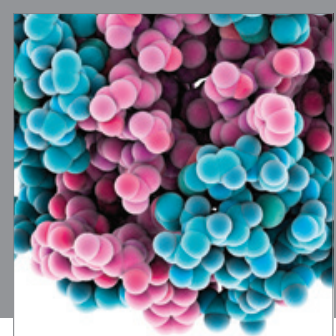

Journal of
Diabetes Research

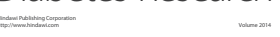

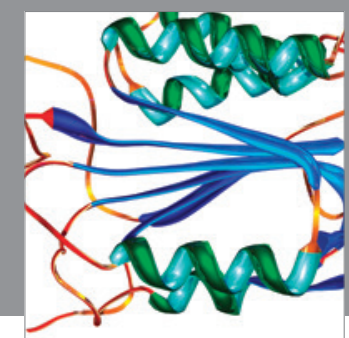

Disease Markers
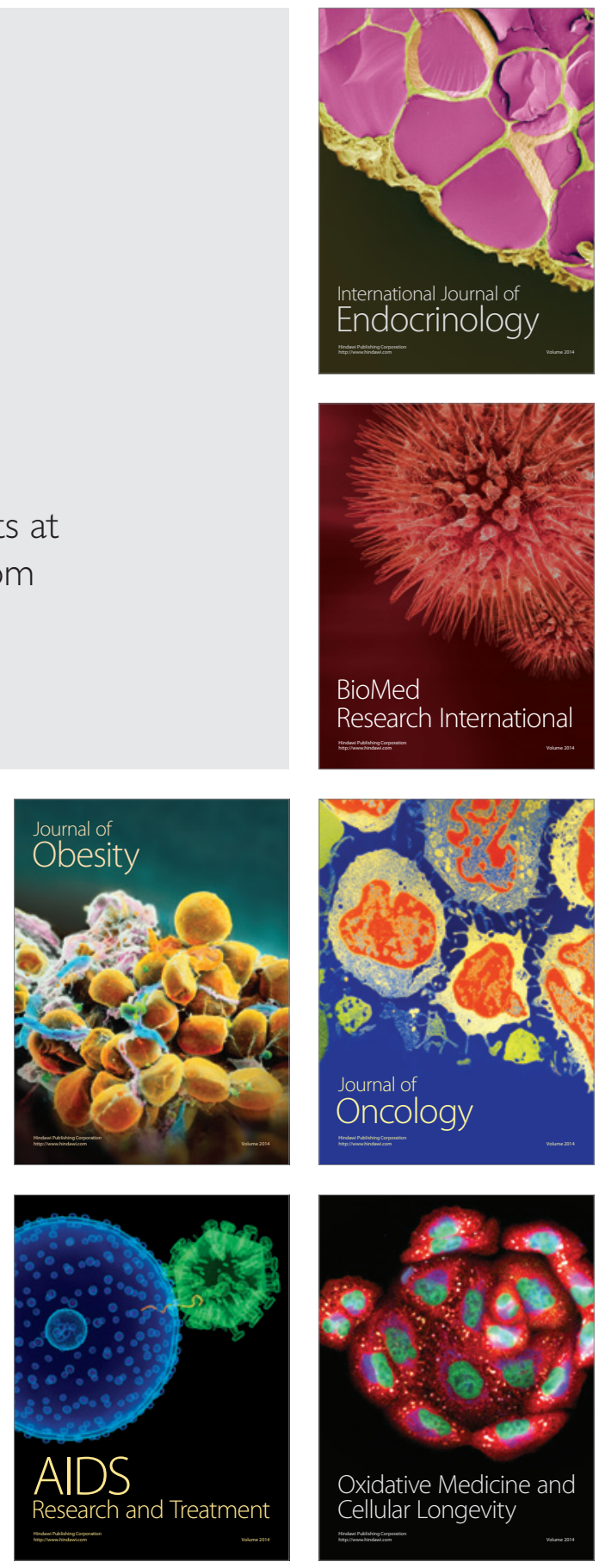